\title{
POHŘEBIŠTĚ PRAŽSKÉHO HRADU A MOŽNOSTI JEJICH SOCIÁLNÍ INTERPRETACE
}

\author{
JAN FROLÍK - SYLVA KAUPOVÁ
}

\begin{abstract}
Abstrakt: Po archeologické stránce byla vyhodnocena raně středověká pohřebiště v areálu Pražského hradu a nejbližšim zázemí se zaměrením na možný sociálni status pohřbených (hrobová výbava, úpravy hrobových jam a hrobů, uspoŕádání pohřebišt', demografické ukazatele). Takto stanovený sociální status pohřbených byl ověrován analýzou izotopů stravy. U dvou pohřebišt byl doložen vysoký status pohřbených, kterému odpovidá strava s vysokým obsahem živočišných proteinů. Stejné pozorování platí pro ojedinělé elitni hroby. Pro dvě pohřebiště související s vesnickým (zemědělským) zázemím se předpokládá nižši zastoupení stravy s obsahem živočišných proteinů a nizká variabilita ziskaných dat.
\end{abstract}

Klíčová slova: pohřebiště - Pražský hrad - raný středověk - elita - stabilní izotopy - výživa - sociální diferenciace.

\section{Prague Castle Burial Grounds and Their Possibile Social Interpretation}

\begin{abstract}
Medieval burial grounds located within the Prague Castle complex and its immediate hinterland were investigated in archaeological terms, with focus on the possible social status of the buried (grave goods, adjustment of the burial pits and graves, the layout of the burial grounds, demographic markers). Social status data provided by the research was confronted with the results of stable isotope analysis of diet. Two burial grounds showed a high social status of the people buried there, corresponding to food with a high content of animal proteins. The same is true for solitary graves of social elites. For two burial grounds connected with the rural (agricultural) hinterland, a lower proportion of animal proteins is presumed, as well as a low variability of the acquired data.
\end{abstract}

Key words: burial ground - Prague Castle - early Middle Ages - elite - stable isotopes - nutrition - social differentiation.

\section{1. Úvod}

Pražský hrad je nejen státním centrem s více než tisíciletou kontinuitou, ale také (nebo právě proto) také objektem dlouhodobě archeologicky zkoumaným. Ne nepodstatnou část archeologických nálezů tvoří pohřebiště, mezi nimiž zaujímají důležité postavení ta, která datujeme do konce 9. a do 10. století. Jejich význam spočívá především $\mathrm{v}$ tom, že jsou současná s počátky Pražského hradu, a tudíž jsou také svědectvím o lidech, kteří ve stejném období na Pražském hradě žili a umírali. Významu tohoto pramene dlouho neodpovídala míra zpracování jednotlivých hrobů i celých pohřebišt'. Tento nedostatek se daří odstraňovat od roku 2005 v rámci grantových projektů (obr. 1). V současné době jsou k dispozici detailní katalogy pohřebišt' z nejbližšího zázemí Pražského hradu (Královská zahrada [KZ], Jízdárna [V-JíZ], Lumbeho zahrada [Z-JÍZ], Jelení ulice [JEL-LZ] - Tomková, ed., 2005; 2006; Frolík-Smetánka 2014; Frolík a kol. 2014; k topografii pohřebišt' z okolí Pražského hradu viz Tomková-Frolík 2005), alespoň předběžně je zpř́istupněno pohřebiště Střešovice-Triangl (SC; Frolíková-Kaliszová 2014). Neúplné informace jsou k dispozici o pohřebišti Prašný most (též Milady Horákové - PM; Tomková 2013). ${ }^{1} \mathrm{~K}$ dispozici je také katalog pohřebiště ze II. nádvoří Pražského hradu, tj. okolí kostela Panny Marie (Frolík 2015; viz též Frolík 2013). Výzvou pro dokončení projektu je vypracování katalogu pohřbů ze III. hradního nádvoří. Potřebné údaje o skupině nejstarších hrobů z okolí monolitu v západní části nádvoří však existují (Borkovský 1941; 1939-1946). Shromážděná data dávají možnost nejen porovnávat $\mathrm{z}$ tohoto hlediska Pražský hrad s ostatními významnými raně středověkými centry, ale také srovnávat pohřebiště mezi sebou. Je možné pokusit se určit, zda se pohřebiště odlišují ve vybavení a uspořádání a zda je uživaly různé části komunity obývající Pražský hrad.

1 Poněkud odlišným způsobem bylo zpř́stupněno také rozsáhlé pohřebiště na Loretánském náměstí na Hradčanech, které se však chronologicky míji se sledovaným obdobím (Boháčová-Blažková 2011). Stejně tak pomíjíme pohřebiště v areálu Strahovského kláštera a v Břevnově na Malovance, jejichž vzdálenost od areálu Hradu je př́iliš veliká (Dragoun 2006; Tomková 2006, 122-127). 


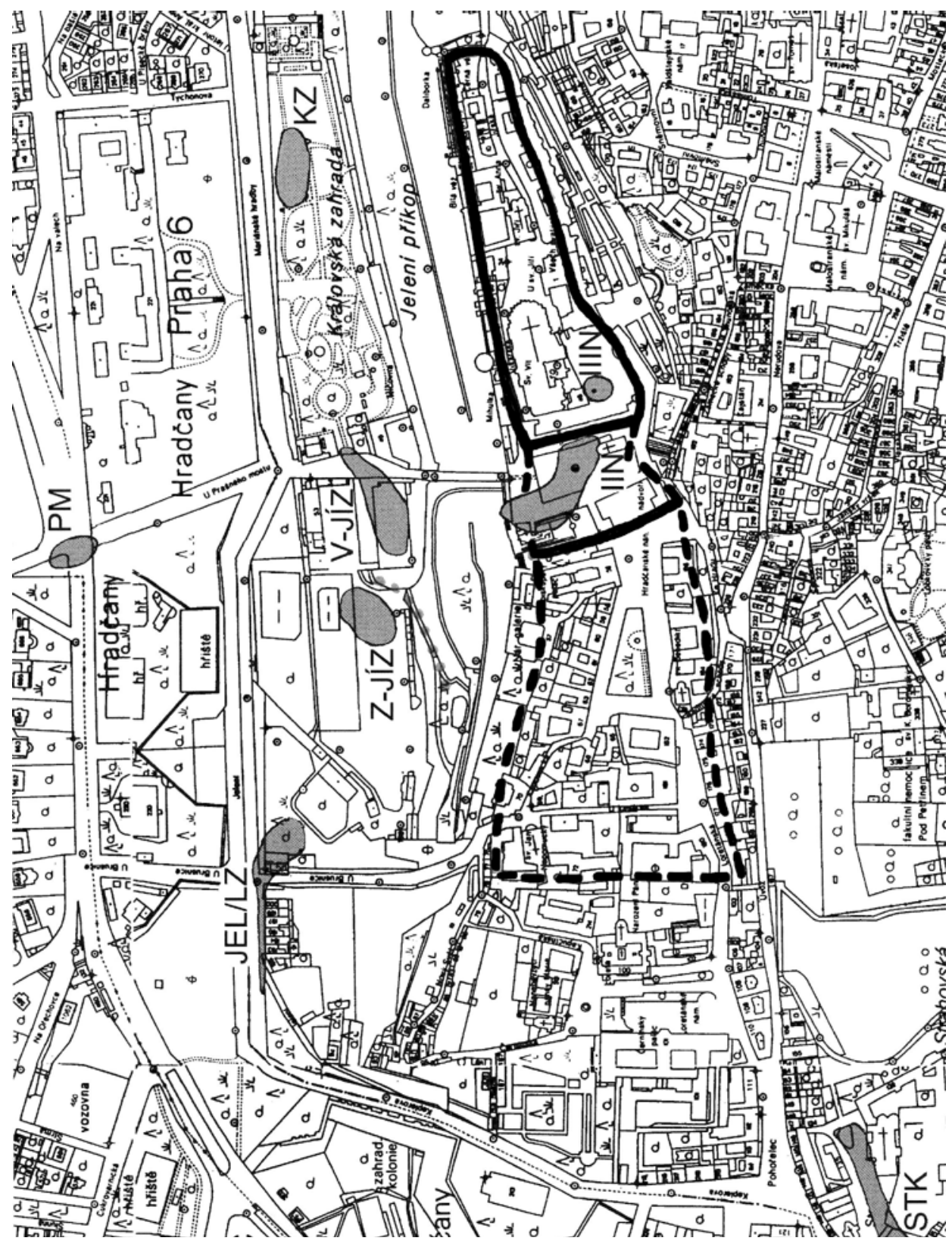

Obr. 1. Praha - Hrad a nejbližší zázemí s polohou jednotlivých pohřebišt' 9. až 11. století. JEL/LZ - Jelení ulice a Lumbeho zahrada I; KZ - Královská zahrada; PM - Prašný most/Milady Horákové; SC - Strahovská cihelna, součástí tohoto pohřebiště je také poloha Střešovice-Triangl; STK - Strahovský klášter; V-JÍZ - Jízdárna a u Jízdárny; Z-JÍZ - Lumbeho zahrada/za Jízdárnou; IIN - 2. nádvoří/u kostela P. Marie; IIIN - 3. nádvoří, skupina pohřbů u monolitu. Plnou čarou vyznačen rozsah Pražského hradu, čárkovaně předhradí na Hradčanech. Vypracoval J. Frolík.

Abb. 1. Prag - Burg und nächstes Hinterland mit Lage der einzelnen Gräberfelder des 9. bis 11. Jhdts. JEL/LZ - Hirschstraße und Lumbe-Garten I; KZ - Königsgarten; PM - Pulverbrücke/Milada Horáková-Str.; SC - Ziegelei Strahov, Teil dieses Gräberfeldes ist auch die Lage Stř̌šovice-Triangl; STK - Kloster Strahov; V-JÍZ - Reithalle und an der Reithalle; Z-JÍZ Lumbe-Garten/hinter der Reithalle; IIN - II. Burghof/an der Marienkirche; IIIN - III. Burghof, Gruppe der Bestattungen am Granitmonolith. Die schwarze Linie kennzeichnet den Umfang der Prager Burg, die gestrichelte die Vorburg auf dem Hradschin. Erstellt von J. Frolík. 


\section{Pohřebiště v areálu Hradu a nejbližším zázemí}

Srovnání jednotlivých pohřebišt' se musí vyrovnat s různým stupněm jejich poznání a dokonce možnosti je poznat. Nerovnoměrné jsou poznatky o úplnosti pohřebišt' a jejich velikosti (počet hrobů). Výjimkou je pohřebiště v Lumbeho zahradě, které jako jediné bylo prozkoumáno celé (obr. 2), a analýza prokázala, že eventuální úbytek hrobů od konce pohřbívání do současnosti byl minimální nebo dokonce žádný (Frolík 2014, 6-10). Na opačném pólu stojí pohřebiště v Královské zahradě, které není možné posoudit, protože se z něho dochovalo jen několik izolovaných nálezů a neznáme bezpečně ani přesnou lokalizaci (Tomková 2006, 5-12; 2015). Torzovitě je poznáno pohřebiště na rozhraní Lumbeho zahrady I a Jelení ulice (JEL-LZ; Tomková 2006, 78-104). Zkoumaných 16 hrobů určitě nepředstavuje jeho skutečný původní rozsah. Rozmístění hrobů dokládá, že jeho značné části zanikly při terénních úpravách v novověku. Pohřebiště u Jízdárny (V-JíZ) zahrnuje 66 raně středověkých hrobů (Tomková 2006, 13-77). ${ }^{2}$ Původní počet hrobů byl jistě vyšší, část však zanikla při zemních pracích ve 40. a 50. letech 20. století, část možná již dříve - v místě ulice u Prašného mostu (obr. 3). Nově byla probádána poslední část pohřebiště souvisejícího se zaniklou Strahovskou cihelnou se 49 hroby (Frolíková-Kaliszová 2014) a s neznámým počtem hrobů zjištěným v 19. století (Tomková 2006, 106-114). Opět můžeme konstatovat, že nezjistitelná část pohřebiště zanikla bez výzkumu (obr. 4). Na pohřebišti Prašný most (Milady Horákové - PM) bylo prozkoumáno celkem 83 hrobů (obr. 5). Bezpečně je vymezeno na západní a východní straně, pokračování o nejisté (spíše nevelké?) ploše je možno očekávat severním směrem (Tomková 2013).

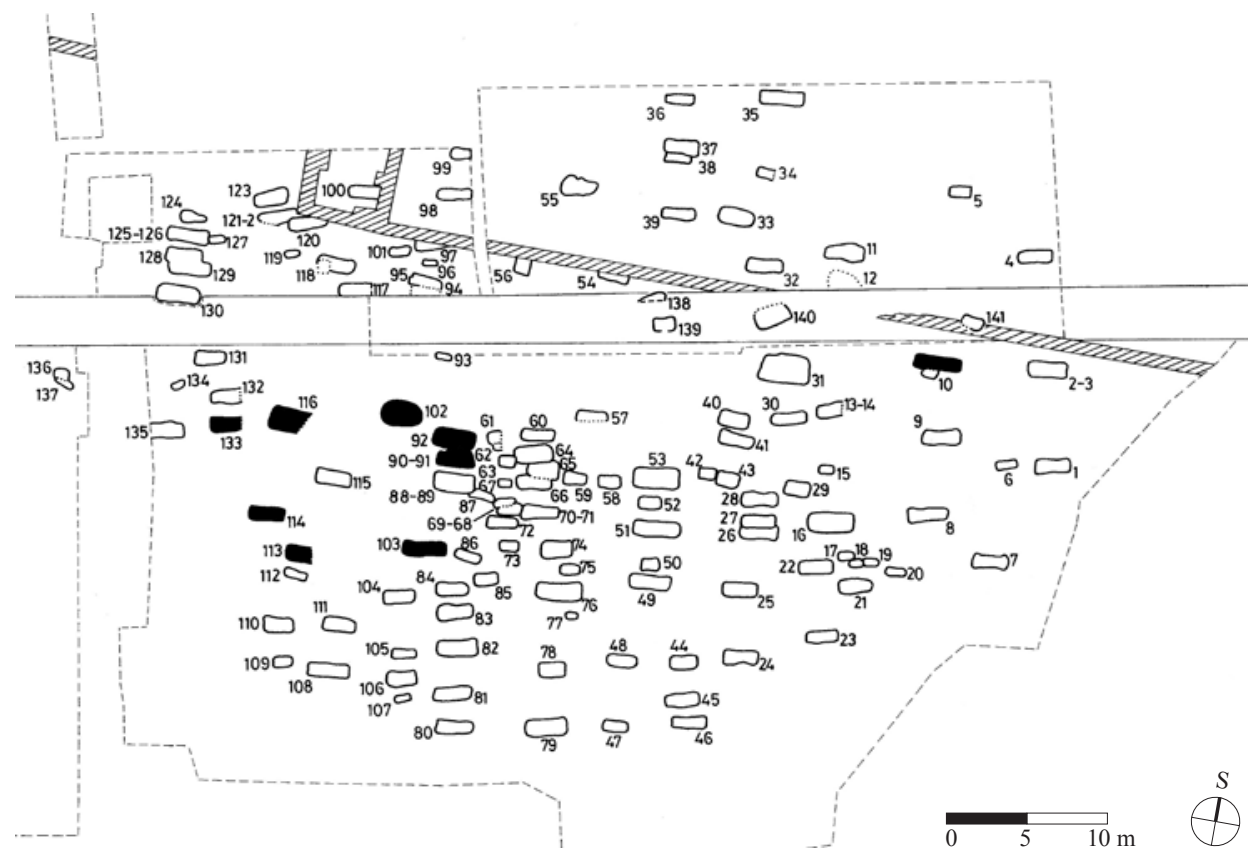

Obr. 2. Praha - Hrad. Celkový plán pohřebiště v Lumbeho zahradě (též za Jízdárnou). Černě označeny hroby, z nichž byly odebrány vzorky na analýzu izotopů. Vypracoval J. Frolík.

Abb. 2. Prag - Burg. Gesamtplan des Gräberfeldes im Lumbe-Garten (auch hinter der Reithalle). Aus den schwarz gekennzeichneten Gräbern wurden die Proben für die Isotopenanalyse entnommen. Erstellt von J. Frolík.

2 Plocha pohřebiště byla znovu využita v raném novověku, s velkou pravděpodobností zde pohřbívala švédská armáda okupující v letech 1648-1649 Pražský hrad (Blažková-Dubská 2006). 


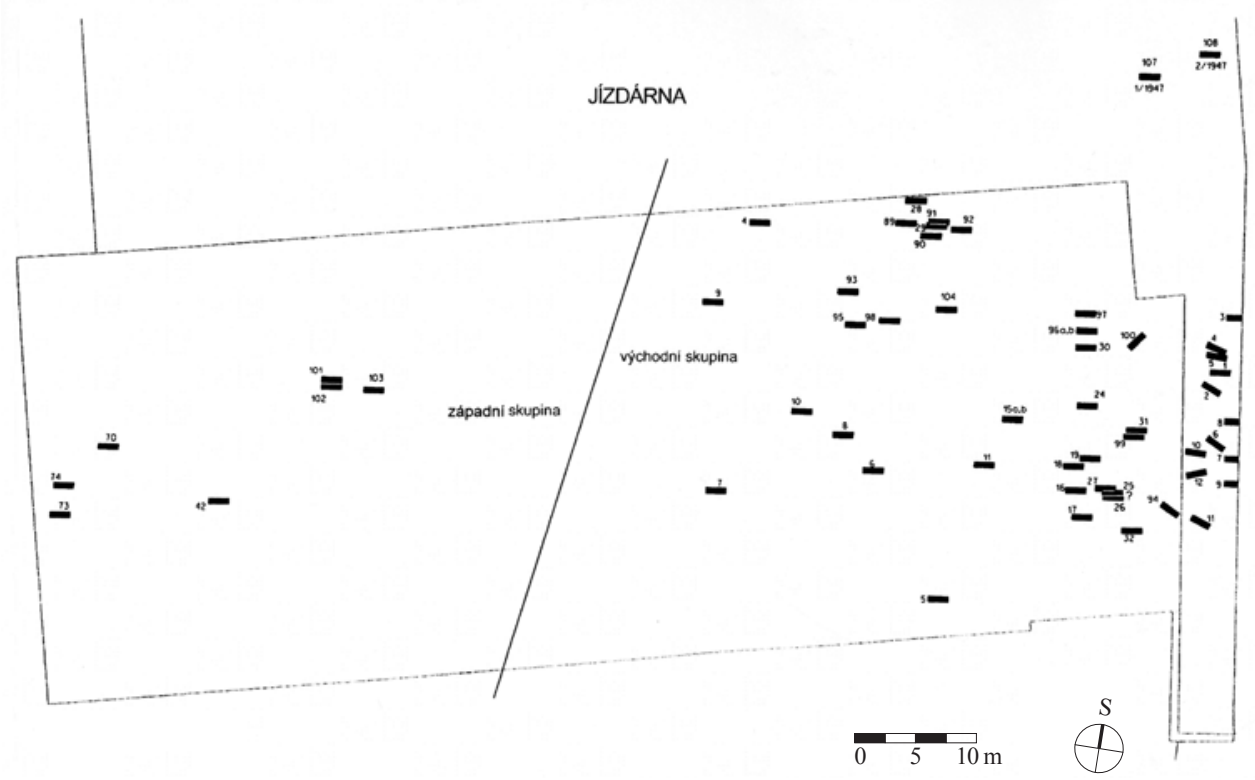

Obr. 3. Praha - Hrad. Celkový plán pohřebiště u Jízdárny Pražského hradu. Podle Tomková 2006.

Abb. 3. Prag - Burg. Gesamtplan des Gräberfeldes an der Reithalle der Prager Burg. Nach Tomková 2006.

Další pohřebiště se nacházejí v areálu Pražského hradu. V místě III. nádvoří (IIIN) bylo během mnoha let výzkumu (1925 až 2000) zjištěno celkem 245 hrobů, které převážně souvisejí s církevními stavbami a s pohřebištěm v Lumbeho zahradě se chronologicky míjejí. Pro srovnání se hodí pouze skupina 13 hrobů v západní části III. nádvoří v okolí monolitu z roku 1928 (Frolík 2013a). Pohřebiště na II. nádvoří s kostelem P. Marie (obr. 6), které zasahuje také na nádvoří IV. a do plochy severně Španělského sálu, čítá 81 hrobů (IIN - Frolík 2015). Starší část je chronologicky souběžná s pohřebištěm v Lumbeho zahradě. Některé jeho úseky zanikly při terénních zásazích, když bylo ve 13. století opuštěno, zčásti dokonce ještě dříve.

Pro srovnání především demografických údajů nám poslouží pohřebiště Jízdárna (V-JÍZ - Blajerová 2006), Milady Horákové/Prašný most (PM - Stránská 2013), Stř̌ešovice-Triangl (SC - Stránská 2014) a II. nádvoří (IIN - Becker 2000; 2001) s dostatečným počtem pohřbených jedinců. Alespoň zčásti lze využít údaje o pohřebištích na III. nádvoří (IIIN) a v Jelení ulici (JEL-LZ). Z charakteristiky jednotlivých pohřebišt' lze stanovit poměr mezi hroby dětí a dospělých. Počet dětských hrobů se pohybuje mezi 11 a 58,8 \%. Nízký počet dětských hrobů byl zjištěn především u torzovitě dochovaných pohřebišst' (např. JEL-LZ). Na III. nádvoří může být nízké zastoupení ovlivněno přetrváváním pohřebiště až do 15 . století. Prakticky stejné nízké zastoupení je doloženo ve skupině nejstarších hrobů v okolí monolitu (11 \%), ale při malém počtu jedinců (18). Asi běžné zastoupení jsme zjistili na pohřebišti Střešovice-Triangl (46,2 \%) a v Lumbeho zahradě (44,8 \% - Blajerová 1992). Více dětských pohřbů je doloženo na kostelním pohřebišti na II. nádvoří $(54,5 \%)$, které se však použivalo až do 13 . století. To neplatí pro pohřebiště Prašný most s vůbec nejvyšším zastoupením dětských hrobů (58,8 \%). Menším počtem překvapí pohřebiště u Jízdárny, kde se pohybuje mezi 15,7 \% a 27 \% podle toho, jak jednotlivé hroby započítáme. Nejnižší číslo zahrnuje pouze antropologicky určené jedince, vyšší číslo zahrnuje i hroby charakterizované jako dětské, z nichž se nedochoval antropologický materiál a které jsou do raného středověku zařazeny pravděpodobně jenom na základě fotografíi nebo určení autora výzkumu.

Pozoruhodné je zastoupení mužských a ženských pohřbů. Vyvážené zjištujeme na III. nádvoří započítaném jako celek (49 \% mužských, 51 \% ženských hrobů - index maskulinity 958 , ale 455 jenom pro skupinu hrobů u monolitu) a do jisté míry také na II. nádvoří (41,5\% mužských, 58,5 \% ženských [Becker 2001] - index maskulinity 708). Mimo areál Pražského hradu 


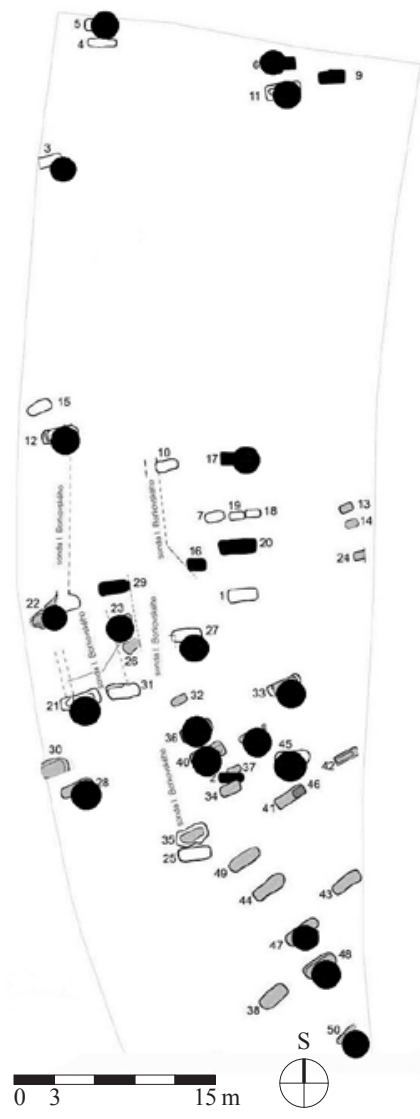

Obr. 4. Praha - Střešovice. Plán pohřebiště v poloze Triangl mezi ulicemi Střešovická a Patočkova. Černými kroužky označeny hroby, $z$ nichž byly odebrány vzorky na analýzu izotopů. Vypracoval J. Frolík.

Abb. 4. Prag - Stř̌ešovice. Planskizze des Gräberfeldes in der Lage Triangl zwischen den Straßen Stř̌šovická und Patočkova. Aus den mit schwarzen Kreisen gekennzeichneten Gräbern wurden die Proben für die Isotopenanalyse entnommen. Erstellt von J. Frolík.

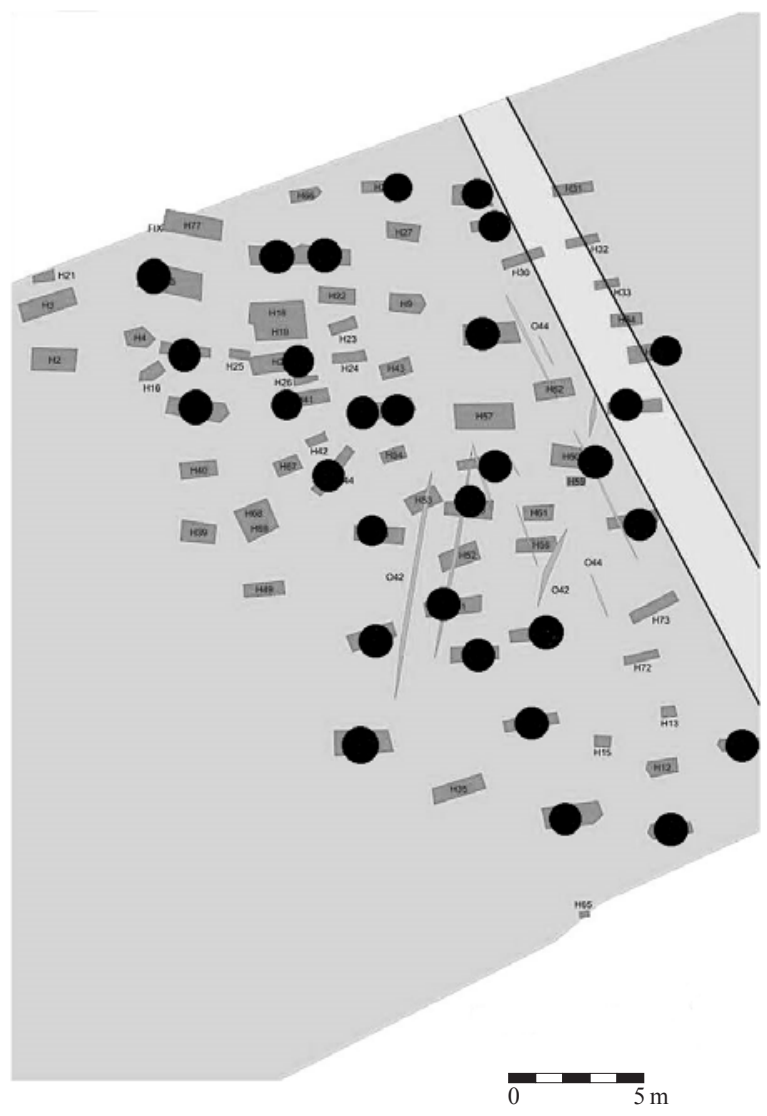

Obr. 5. Praha - Střešovice. Plán pohřebiště na křižovatce Prašný most (ul. Milady Horákové). Černými kroužky označeny hroby, z nichž byly odebrány vzorky na analýzu izotopů. Poslední vzorkovaný hrob se nachází mimo mapový výřez. Světle šedě vyznačena zkoumaná plocha. Vypracoval J. Frolík.

Abb. 5. Prag - Střešovice. Planskizze des Gräberfeldes an der Kreuzung Pulverbrücke (Horáková-Str.). Aus den mit schwarzen Kreisen gekennzeichneten Gräbern wurden die Proben für die Isotopenanalyse entnommen. Das letzte Grab, aus dem eine Probe entnommen wurde, befindet sich außerhalb des Kartenausschnitts. Die untersuchte Fläche ist hellgrau gekennzeichnet. Erstellt von J. Frolík.

jde o nejvzdálenější pohřebiště Střešovice-Triangl (47,4 \% mužských, 52,6 \% ženských - index maskulinity 900). Na ostatních značně převažují pohřby žen. V Lumbeho zahradě ženské hroby tvoří 76,5 \% (index maskulinity 307 - Blajerová 1992) a obdobně vysoké je na pohřebišti JEL-LZ (71 \% - index maskulinity 250). Na pohřebišti Prašný most má index maskulinity hodnotu $273 .^{3}$ Převažující zastoupení žen bylo zjištěno také na pohřebišti V-JíZ (62,5 \% - index maskulinity 600).

Zdá se, že pohřebiště v blízkém hradním zázemí (V-JÍZ, JEL-LZ) a také v Lumbeho zahradě (Z-JÍZ) vykazují obdobný rys, kterým je vysoký podíl žen. Pohřebiště v areálu Pražského hradu (IIN a IIIN) mají zastoupení blízké nebo blížící se očekávanému poměru. Svůj vliv jistě hraje okolnost, že šlo o pohřebiště zčásti mladší a u kostelů. Stejně tak se zdá, že očekávané zastoupení na nejvzdálenějším z pohřebišt' (SC) může reflektovat příslušnost $\mathrm{k}$ jiné sídlištní jednotce než k Pražskému hradu. V případě pohřebiště JEL-LZ (80 \% ženských hrobů) může hrát roli fakt,

3 Za nepublikované údaje o pohřebišti Prašný most jsme vděčni RNDr. Petře Stránské. 


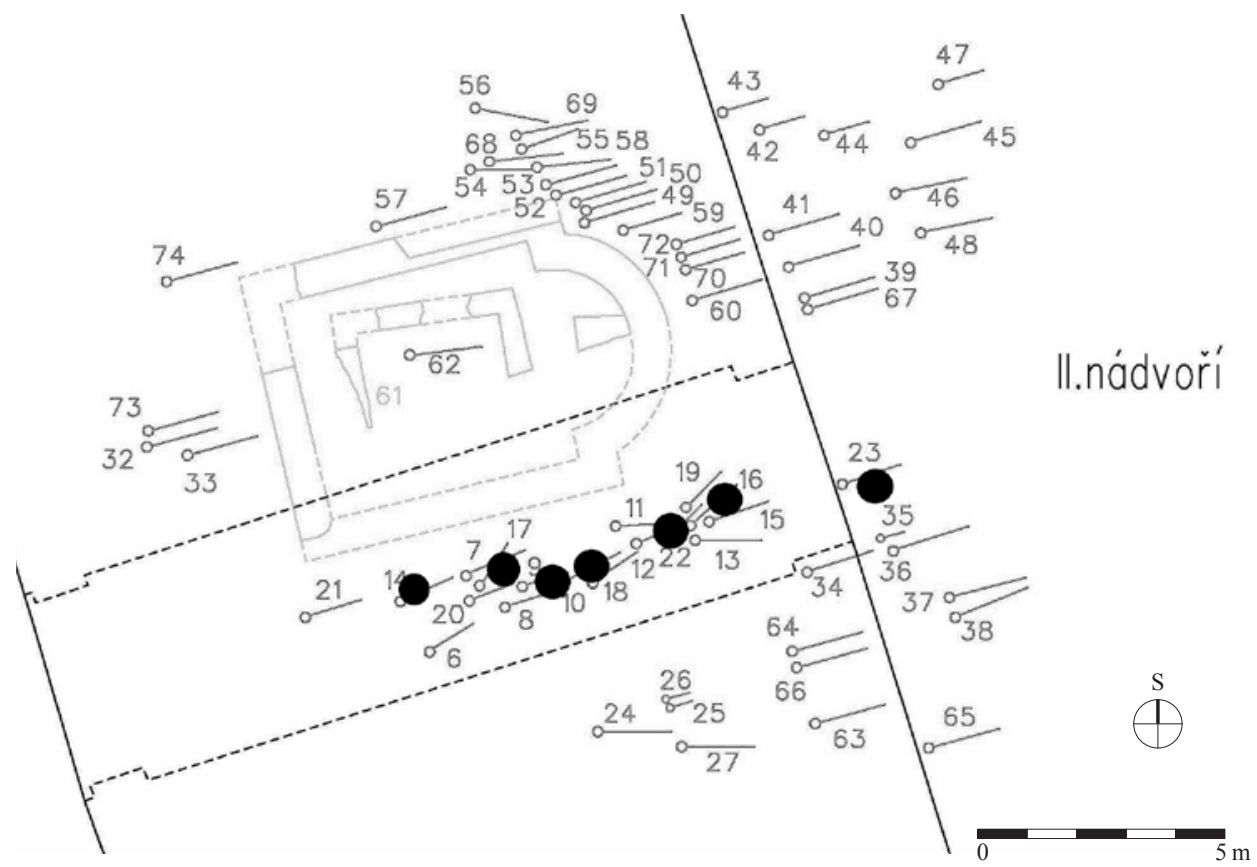

Obr. 6. Praha - Hrad, II. nádvoří a severozápadní křídlo. Hroby v nejbližším okolí zaniklého kostela P. Marie. Černými kroužky označeny hroby, z nichž byly odebrány vzorky na analýzu izotopů. Osmý vzorkovaný hrob se nachází na západním okraji pohřebiště mimo mapový výřez. Vypracovala firma Geo.cz.

Abb. 6. Prag - Burg, II. Burghof und nordwestlicher Flügel. Gräber in der nächsten Umgebung der verschwundenen Marienkirche. Aus den mit schwarzen Kreisen gekennzeichneten Gräbern wurden die Proben für die Isotopenanalyse entnommen. Das achte Grab, aus dem eine Probe entnommen wurde, befindet sich am Westrand des Gräberfeldes außerhalb des Kartenausschnitts. Erstellt von der Firma Geo.cz.

že jde pouze o torzo pohřebiště s nejasnou velikostí zaniklé či nezkoumané části. U pohřebiště u Jízdárny (V-JÍZ) činí podíl žen 62,5 \%, ale klesne téměř k očekávanému vyrovnanému zastoupení, pokud se započtou i hroby s nejistým zařazením do raného středověku (55\%). Přes uvedené připomínky k úplnosti těchto pohřebišt' je nápadné, že pohřebiště v nejbližším zázemí Pražského hradu vykazují podobnou charakteristiku. Kdybychom sečetli údaje za čtyři zmíněná pohřebiště, vychází poměr mužských a ženských hrobů $29,7 \%$ : 70,3 \% ve prospěch žen.

Jen částečně je možné porovnat uspořádání pohřebišt'. Zvláštní skupinu tvoří obě pohřebiště v areálu Pražského hradu (IIN a IIIN), na nichž se setkáváme s etážovým pohřbíváním v blízkém okolí církevních staveb (kostel P. Marie, rotunda a posléze bazilika sv. Víta). Ve větších vzdálenostech od kostelů byly archeologicky odhaleny různě veliké skupiny hrobů, ale celkové uspořádání nelze rekonstruovat (k II. nádvoří - Frolík 2013). Z našich úvah musíme vyloučit pohřebiště v Královské zahradě, protože o jeho uspořádání není nic známo. Nemůžeme hodnotit ani pohřebiště v Jelení ulici a přilehlé části Lumbeho zahrady (JEL-LZ), z nichž jsou známa jenom izolovaná torza. Pohřebiště u Jízdárny (V-JíZ) je v důsledku nepříznivých podmínek pro archeologický výzkum neúplné, přičemž počet zničených/nezkoumaných hrobů nelze odhadnout. Zdá se, že je spíše skupinové a s náznaky uspořádání do řad ve východní části (Tomková 2006, 61-62). Je také možné, že se umístění hrobů vyvíjelo od skupinového uspořádání k řadovému, ale vývoj nebyl dokončen. Pohřebiště Střešovice-Triangl (SC) vykazuje spíše řadové uspořádání, přestože je pouze výsekem z mnohem většího hřbitova. Mezery mezi hroby odůvodněně padají na vrub terénním zásahům v novověku (Frolíková-Kaliszová 2013, 316-317). V podstatě jednoznačně je do řad uspořádáno pohřebiště Prašný most/Milady Horákové (PM - Tomková 2013). Celkový závěr je obtížný. Řadové uspořádání vykazují pohřebiště s větším počtem hrobů (PM, SC, Z-JíZ), ale tento úsudek mohla ovlivnit skutečnost, že pohřebiště bylo možné detailně zkoumat a dokumentovat. 
Přes tuto výhradu se však zdá, že pohřebiště u Jízdárny (V-JÍZ) se odlišovalo skupinovým uspořádáním. Odlišnost může být výsledkem rozdílného chování skupiny, která zde pohřbívala, ale také může mít význam chronologický. Proto se nezdá vhodné nadále spojovat pohřebiště v Lumbeho zahradě (Z-JÍZ) a u Jízdárny (V-JÍZ) do jednoho celku a jako takový ho posuzovat (odlišně Tomková 2006, 13).

Při zkoumání velikosti a úpravy hrobových jam narazíme na některé opakující se jevy, které mohou mít význam při interpretaci pohřebiště nebo jednotlivých pohřbů, i když nám jejich vysvětlení může unikat. Srovnávat můžeme opět především dobře dokumentovaná pohřebiště (Lumbeho zahrada, Střešovice-Triangl), u ostatních lze některé jevy konstatovat, ale nikoliv kvantifikovat. Pozornost se obvykle soustřed'uje na hrobové jámy plošně nadměrné nebo o větší hloubce. Na pohřebišti Lumbeho zahrada je to celkem 27 hrobů (ze 148). Pro některé jámy je charakteristická značná délka (5 hrobů), ojediněle též nadměrná šířka (1 hrob). Většina je nadměrná v obou rozměrech (7 hrobů). Specifickou skupinu představují hroby dětí, často velmi mladých, tj. novorozenců či kojenců (14 hrobů), kde je hrobová jáma „zbytečně“ velká (obr. 7). Většina hrobů s větší jámou byla vybavena doplňky (21), často velmi či mimořádně bohatými (12 hrobů). Potvrzuje se pozorování, že velikost hrobové jámy může odrážet významnější postavení pohřbeného, byt' vyjádřené zprostředkovaně (významné postavení rodičů malých dětí - mezi hroby s relativně velkými jámami jsou i pohřby novorozence či kojence).

Obdobně je tomu u hloubky hrobové jámy. Za hluboké lze považovat hrobové jámy, jejichž zahloubení do podloží činilo více než 0,4 m (39 hrobů). Sedmnáct z nich zároveň náleží k hrobům plošně nadměrným. Pokud omezíme svá pozorování na hroby se zahloubením do podloží větším než $0,6 \mathrm{~m}$, evidujeme jich deset. Pouze dva nejsou také plošně nadměrné. Hroby hlubší než $0,7 \mathrm{~m}$ jsou pouze čtyři (z toho 1 plošně nadměrný). Větší hloubku mají pouze dva hroby (1 plošně nadměrný). Skupina těchto 16 nejhlubších hrobů tvoří nadpoloviční počet hrobů bohatě vybavených či s jinými znaky elitního postavení (miniatury zbraní, ostruhy). Zdá se tedy, že větší hloubka hrobu je důležitým faktorem pro významnější (?) postavení pohřbeného.

$\mathrm{Na}$ ostatních pohřebištích evidujeme plošně nadměrnou hrobovou jámu na pohřebišti JEL/LZ, a to jednou (Březinová-Turek 1999), ve vnitřním hradním areálu je to ve skupině hrobů v okolí monolitu známý hrob „bojovníka“ (IIIN199), který jako jediný má také dřevěnou komoru (Tomková 2005, 161). Podrobně zdokumentována byla situace na pohřebišti Střešovice-Triangl (SC; Frolíková-Kaliszová 2014, 319-321). Zde evidujeme sedm plošně velkých hrobů (k tomu jeden další na hranici limitu), u dětských hrobů byla hrobová jáma nepoměrně velká vůči kostře ve čtyřech prrípadech, další dva jsou sporné. Celkem jde maximálně o 14 hrobů. Při srovnání s pohřebištěm v Lumbeho zahradě zjistíme, že podíl nadměrných hrobových jam je ve Střešovicích dokonce vyšší (Z-JÍZ 18,9 \%, SC 28,6\%). Nadměrná velikost hrobové jámy mohla vyjadřovat významnější postavení pohřbeného, avšak ve Střešovicích zřejmě nemohla být podpořena stejně bohatou výbavou (pouze 4 hroby).

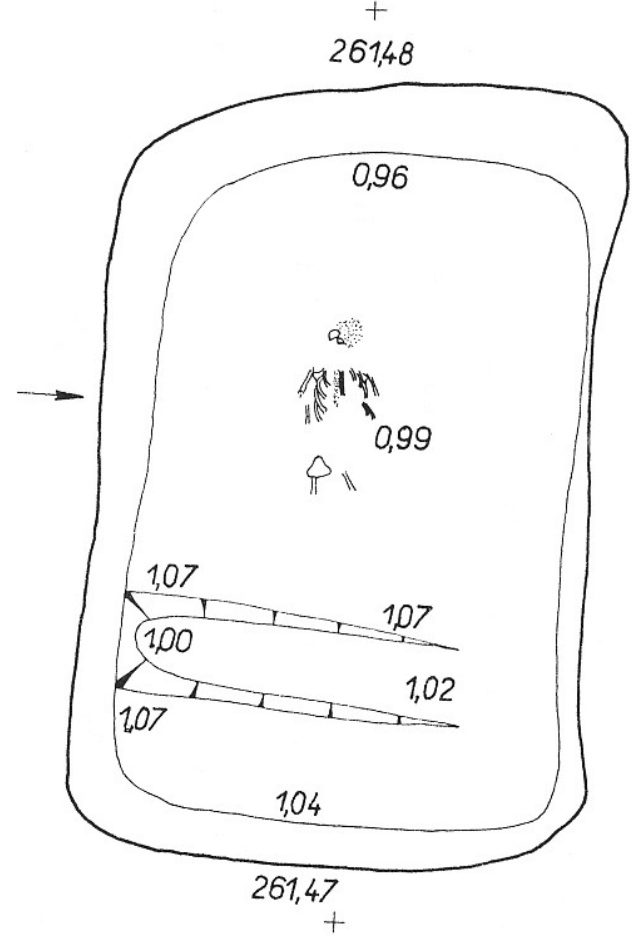

Obr. 7. Praha - Hrad, Lumbeho zahrada. Hrob H40 jako příklad dětského pohřbu s nadměrnou hrobovou jámou. Podle Frolík-Smetánka 2014.

Abb. 7. Prag - Burg, Lumbe-Garten. Grab $\mathrm{H} 40$ als Beispiel einer Kinderbestattung mit übergroßer Grabgrube. Nach Frolík-Smetánka 2014. 
Při úpravách hrobové jámy se v určité míře používalo dřevo nebo kámen. Pro většinu pohřebišt' máme $\mathrm{k}$ dispozici pouze informace o jejich ne/přítomnosti bez potřebných detailů. Obvykle jsou zaznamenány pouze vzácně se vyskytující formy. Mimořádnou úpravu hrobové jámy představuje zřízení dřevěné komory, kterou evidujeme u již zmíněného hrobu „bojovníka“ na III. nádvoří (hrob IIIN199) a v Lumbeho zahradě (jeden případ jistý, jeden pravděpodobný). Do stejného časového období náleží ještě hrob K1 v interiéru svatovítské rotundy (Tomková 2005, 161), který je interpretován jako hrob Boleslava I. (Frolík 2005, 30-31). Rakev z vydlabané části kmene je známa $\mathrm{z}$ uvedených pohřebišt' pouze $\mathrm{v}$ Lumbeho zahradě (dva hroby - obr. 8) a u Jízdárny (jeden hrob). Ve všech př́ípadech šlo o dětské pohřby, ve dvou, podle výbavy, o děvčátka. Rakev z kmene se považuje za znak vysoce elitního prostředí; což na Pražském hradě dokládá užití v hrobě JK98 v bazilice sv. Jiří, připisovaném knížeti Boleslavu II. († 999). Jiným př́źznakem elitního postavení pohřbeného jsou rakve spojované železnými pásovými kováními (Galuška 2005). Takový hrob je z Pražského hradu a jeho zázemí znám pouze jeden, a to na III. hradním nádvoří (hrob IIIN194).

Specifické využití kamene při úpravě hrobové jámy je jeho použití ve větší velikosti za hlavou (Lumbeho zahrada - 10 hrobů, Jízdárna -9 hrobů), přičemž byl často postavený na úzkou hranu, popř. byl tím v hrobě největším (obr. 9). Obdobná poloha kamene u nohou je zaznamenána jenom v Lumbeho zahradě. Specifická úprava sestávala z kamenné schránky (hrobky) překryté třemi kamennými deskami (jeden dětský hrob u Jízdárny). V Lumbeho zahradě se jeho podobě blíží pouze jeden dětský hrob, kde dítě zakryl domečkovitý útvar z pěti kamenů postavených na výšku. Kamenná schránka/hrobka - vytvořená z rozměrnějších opukových dlaždic - byla objevena také na II. nádvoří. Kámen je rovněž spojován s blokací mrtvého, tj. s cílem zabránit revenanci. Kromě pohřebiště v Lumbeho zahradě, kde se takto interpretuje použití kamene $\mathrm{v}$ jednom hrobě (a $\mathrm{v}$ jednom dalším méně přesvědčivě), ho zaznamenáváme zcela ojediněle. V této souvislosti je významný pouze jeden hrob na pohřebišti Jízdárna (Smetánka 1988). O podobné opatření mohlo jít také v Jelení ulici/Lumbeho zahradě, kde lebku starší kostry v hrobě po přmístění překryla mohylka z kamenů (Tomková 2006, 89, 102).

Pohřebiště v Lumbeho zahradě nevydalo, stejně jako ostatní pohřebiště v blízkém zázemí, příliš výrazné svědectví o eventuální křest’anské víře pohřbených osob. Se značnou opatrností můžeme uvažovat jako o křest’anských symbolech pouze o některých motivech na gombících a předpokládat, že jejich nositelé znali či chápali význam použitých symbolů (kř́rž, ochranitelská ruka/ Manus Dei? - pohřebiště Lumbeho zahrada, Královská zahrada - Sklenáŕ-Sláma 1976). Kdybychom se omezili na nálezy, u nichž je vztah ke křest’anství bezprostřední, zjistíme jediný - bronzovou sošku Ukřižovaného se stopami emailu, která původně sloužila jako kování (schránky? knihy?) - na pohřebišti na II. nádvoř́ z doby kolem roku 1000 (Kubková 1997). Našla se ve hřbitovní vrstvě, takže eventuální spojitost $\mathrm{s}$ některým $\mathrm{z}$ hrobů neznáme. Jednoznačný vztah ke křest’anství logicky mají pohřbení u nejstarších hradních kostelů (kostel Panny Marie - IIN) a u rotundy sv. Víta (pohřebiště IIIN). Skupinka hrobů v okolí monolitu by měla předcházet postavení jakékoli církevní stavby.

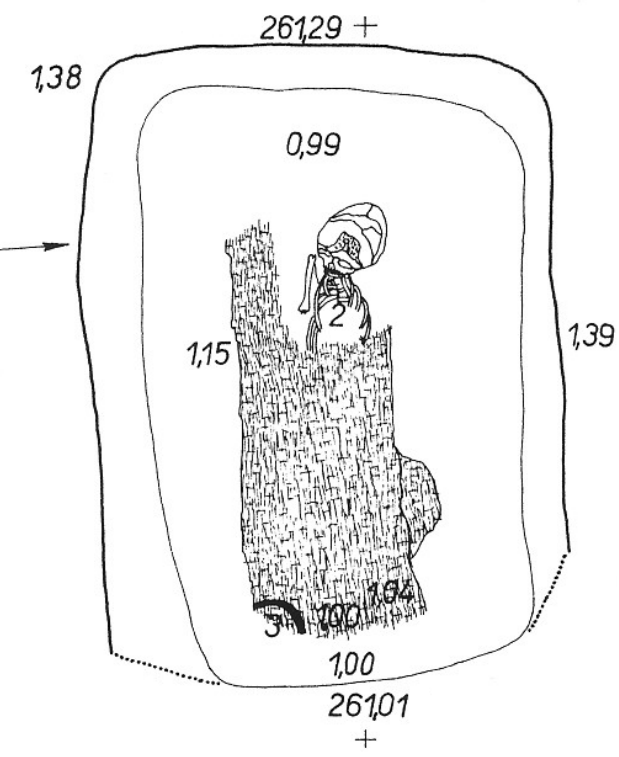

Obr. 8. Praha - Hrad, Lumbeho zahrada. Hrob H43 jako př́iklad dětského hrobu v rakvi z kmene stromu. Podle Frolík-Smetánka 2014.

Abb. 8. Prag - Burg, Lumbe-Garten. Grab $\mathbf{H} 43$ als Beispiel eines Kindergrabes mit Baumsarg. Nach FrolíkSmetánka 2014. 
Ani stop předkřestanských zvyklostí neevidujeme na ostatních pohřebištích mnoho. Pozoruhodné jsou dva hroby, jeden mužský (pohřebiště Jízdárna) a druhý ženský (Lumbeho zahrada), $v$ obou př́ípadech jde o doklad magických předkřest'anských praktik (Smetánka 1988). O předkřest’anských představách se uvažuje i u druhotných zásahů do kostry, které jsou vykládány jako snaha zabránit návratu pohřbeného mezi živé (revenanci). V Lumbeho zahradě jich bylo zjištěno celkem šestnáct (12 manipulací s lebkou, 4 s nohami), v dalších šesti případech si nejsme jisti (zásahy v oblasti hrudníku). Na ostatních pohřebištích nejsou podobná opatření doložena. ${ }^{4}$

Při úvahách o postavení konkrétního jedince $\mathrm{v}$ tehdejší společnosti se nejčastěji se zaměřuje pozornost na nálezy učiněné $\mathrm{v}$ hrobech (milodary, přídavky). Také z tohoto hlediska jsou mezi pohřebišti Pražského hradu značné rozdíly. Nejbohatší vybavení bylo zjištěno u osob pohřbených na pohřebišti v Lumbeho zahradě.

Hodnotíme-li pohřebiště podle jednotlivých kategorií nálezů, zejména mimořádných, převažuje ženský šperk. V mužských hrobech považujeme za mimořádné nálezy zbraně a vybavení jezdce (ostruhy). Ze zbraní můžeme brát do úvahy pouze sekeru. V Lumbeho zahradě se našly dvě, obě v netypické podobě miniatur v dětských hrobech. Přímo v areálu Pražského hradu byla objevena sekera na III. nádvoří v hrobě „bojovníka“ (IIIN199). Nedochovaný nález je zmiňován z pohřebiště ve Strahovské cihelně (Tomková 2005, 220-221). Celkem můžeme u Pražského hradu a jeho zázemí napočítat čtyři sekery. Ani hrobů s ostruhami není mnoho, početně převažují ty v Lumbeho zahradě (tři hroby). Další nálezy se nedochovaly (Královská zahrada, Strahovská cihelna - Tomková 2005, 219). Nový objev byl zaznamenán na pohřebišti Střešovice-Triangl (SC - hrob 40 - Frolíková-Kaliszová 2014). Poslední byl nalezen v druhotné poloze na III. nádvoří (zásyp hrobu IIIN99). Souhrnné číslo se za Pražský hrad a okolí zastaví na nejméně sedmi hrobech. Luxusní zbraní byl meč doložený pouze v jediném hrobě (IIIN199) přímo v areálu Pražského hradu. Nevelký počet hrobů se zbraněmi a jezdeckou výstrojí je odrazem relativně malého zastoupení mužských hrobů jako takových.

Šperky, se kterými se setkáváme jak v ženských, tak i mužských hrobech, jsou gombíky. V Lumbeho zahradě jsme zaznamenali 20 exemplářů $\mathrm{v}$ osmi hrobech. Na dalších pohřebištích jsou zastoupeny podstatně méně (Královská zahrada - jeden; Stř̌ešovice-Triangl - osm, a to v jednom hrobě - Frolíková-Kaliszová 2014, 320; Prašný Most/Milady Horákové - minimálně dva, v jednom hrobě - Tomková 2013, 50). Celkový počet činí 11 kusů. Mezi náušnicemi početně

4 Pro úplnost je třeba dodat, že ve Strahovském klášteře byl prozkoumán hrob mladého jedince, který byl druhotně otevřen a kosti pohřbeného spáleny (Sommer 1985, 195). U jiného hrobu zjišt ujeme jako doklad manipulace dislokované kliční kosti (Dragoun 2006, 142). 
dominují v Lumbeho zahradě hrozníčkovité (celkem 33 v sedmi hrobech). Na ostatních pohřebištích jsou zastoupeny podstatně méně (13 kusů v pěti hrobech). Nejvýznamnějš́i je zřejmě nález $\mathrm{v}$ hrobce v kostele P. Marie, který je interpretován jako místo posledního odpočinku knížete Spytihněva I. († 915) a jeho neznámé manželky (asi † 918 - Borkovský 1953, 180-181; FrolíkMaříková-Kubková-Růžičková-Zeman 2000, 79-80). Další byly zjištěny ve třech hrobech na pohřebišti Jízdárna a v jednom hrobě v Jelení ulici (Tomková 2005, 231). Náušnice bubínkové známe pouze z pohřebiště Lumbeho zahrada (35 kusů ve čtyřech hrobech - Frolík a kol. 2014, 47-59). V Lumbeho zahradě se naproti tomu málo vyskytují náušnice z okruhu tzv. podunajského šperku (určitě dva kusy, pravděpodobně další dva), zatímco z ostatních pohřebišt' je jich doloženo deset (Jízdárna - pět kusů; Jelení ulice - pět kusů; celkem v šesti hrobech). Na těchto pohřebištích najdeme také kroužkovité náušnice s uzlíčky (čtyři kusy ve třech hrobech), všechny v nejjednodušší formě. Meandrovité náušnice jsou zastoupeny u Jízdárny a na pohřebišti Jelení ulice (celkem tři kusy). Náušnice se spirálovitým závěskem byla objevena v jediném exempláři na pohřebišti u Jízdárny (Tomková 2005, 228-231).

Kaptorgy nacházíme kromě Lumbeho zahrady (6 kusů) jenom na pohřebišti u Jízdárny (2 kusy). Nově byla kaptorga objevena také na pohřebišti Střešovice-Triangl (Frolíková-Kaliszová 2014, 320). Rolničky nejsou mimo Lumbeho zahradu doloženy. Další kategorie nálezů shrneme pouze sumárně. Skleněných korálků známe z Lumbeho zahrady 366 kusů a z ostatních pohřebišt' 108, u jantaru je poměr $67: 28$, u kovových (obvykle stříbrných) perel $24: 7$ a u perel z drahých kamenů či polodrahokamů $38: 1$. Pohřebiště v Lumbeho zahradě bylo bohatě vybaveno záušnicemi (záušnice s očkem $67: 22$, esovité záušnice $62: 22$ ). Souhrnně porovnáme též výskyt věder (Lumbeho zahrada šest kusů, ostatní pohřebiště deset kusů - Frolík a kol. 2014, 67-73). Obdobně je tomu s keramickými nádobami (Lumbeho zahrada 14 kusů, ostatní pohřebiště nejméně 31 kusů, pokud zahrneme i nedochované nálezy - Tomková 2005, 289-290).

Toto jednoduché porovnání pohřebiště v Lumbeho zahradě s ostatními na Pražském hradě a v jeho blízkém zázemí potvrdilo v literatuře již popsanou skutečnost, že je nálezově velmi bohaté a především v počtu předmětů z drahých kovů převyšuje ostatní soubory. Významně jsou na něm zastoupeny také hroby s plošně velkou hrobovou jámou a jejími méně častými úpravami (hrobová komora) a hroby s rakvemi z kmene. Pohřebiště vně opevnění Pražského hradu spojuje převaha ženských hrobů nad mužskými. Z tohoto schématu se zčásti vymyká jen pohřebiště Střešovice-Triangl, kde je poměr téměř vyrovnaný. Vysvětlení může souviset se vzdáleností pohřebiště od Pražského hradu a jeho pravděpodobnou příslušností k vesnickému/satelitnímu sídlišti v zázemí. S nově prozkoumanými pohřebišti Střešovice-Triangl a Prašný most/Milady Horákové spojuje Lumbeho zahradu jejich převážně řadové uspořádání (s některými nepravidelnostmi, které vytvářejí početně nevelké skupinky). Řadovou úpravu lze jen nevýrazně prokázat na pohřebišti u Jízdárny.

Při vyčlenění bohatých hrobů, event. těch, které naznačují význam pohřbeného, jsme dospěli $\mathrm{k}$ počtu 33 hrobů na pohřebišti v Lumbeho zahradě (obr. 10). Na všech ostatních pohřebištích jich evidujeme pouze sedm (z toho tři na pohřebišti Střešovice-Triangl; dva u Jízdárny a dva na III. nádvoř́i ve skupině hrobů u monolitu). ${ }^{5}$ Zvlášt' nápadně převažují hroby ženské (10 nebo $13: 1$ Stř̌šovice-Triangl). Vyrovnaná je naopak bilance hrobů mužských (Lumbeho zahrada - dva nebo tři, ostatní pohřebišsě tři). Při porovnávání těchto čísel nelze zapomínat na to, že na některých pohřebištích známe předměty z výbavy, jakou nacházíme v elitních hrobech (ostruhy - Královská zahrada, Strahovská cihelna; gombíky - Královská zahrada), ale bez údajů o konkrétních hrobech.

Komunita žijící na Pražském hradě byla určitě vnitřně rozčleněna, jak vyplývá ze skutečnosti, že jedna její část pohřbívala po delší dobu výlučně (?) v Lumbeho zahradě, zatímco ostatní části/skupiny na jiných (svých?) pohřebištích. Podle nálezů byla skupina pohřbívající v Lumbeho zahradě nejlépe (sociálně) postavena a zároveň nějakým způsobem vymezena (?) vůči ostatním obyvatelům Pražského hradu. Tato výlučnost se udržela po několik generací.

5 Celkově mohlo být zastoupení „elitních“ pohřbů ještě vyšší. Mimořádné postavení pohřbeného mohl vyjádřit způsob, který s ním v rámci úpravy hrobové jámy nebo pohřbu nespojujeme (např. některé formy použití kamene či dřeva v hrobové jámě, pohřbení v oděvu či rubáši ze vzácných látek). Míra vybavení šperky a dalšími předměty mohla odrážet i ochotu či neochotu pozůstalých uložit nebožtíka do jámy společně s cennými předměty, byt' jistě byli pod tlakem dobových konvencí. 


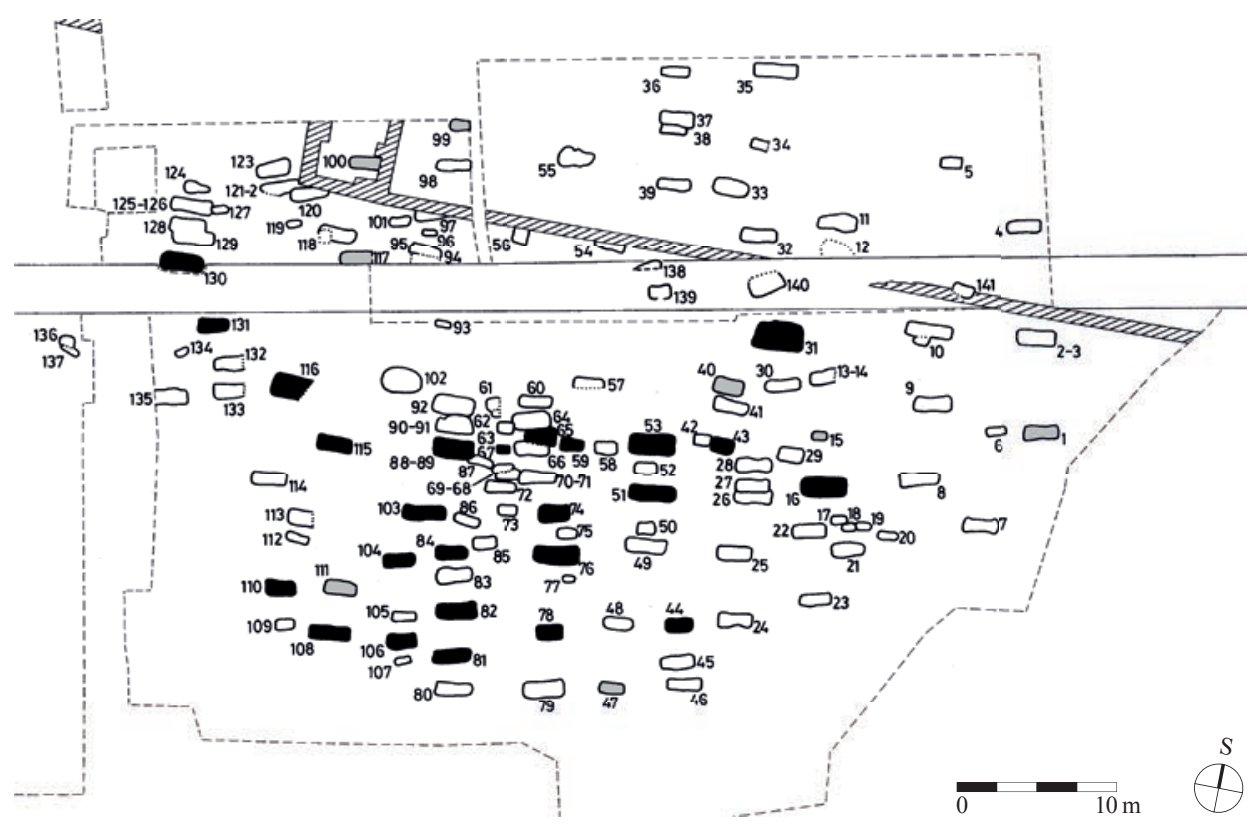

Obr. 10. Praha - Hrad, Lumbeho zahrada. Hroby vyčleněné na pohřebišti jako elitní. Černě vyznačeny hroby s výbavou z drahých kovů nebo zbraněmi či ostruhami a s méně častou úpravou hrobové jámy (plocha, hloubka, velikost). Šedě hroby bud's bohatou výbavou nebo s méně častou úpravou hrobové jámy. Podle Frolík-Smetánka 2014.

Abb. 10. Prag - Burg, Lumbe-Garten. Auf dem Gräberfeld als zur Elite gehörend angesehene Gräber. Die schwarz gekennzeichneten Gräber enthielten eine Ausstattung aus Edelmetallen oder Waffen bzw. Sporen und eine weniger häufige Herrichtung der Grabgrube (Fläche, Tiefe, Größe). Die grauen Gräber zeichnen sich entweder durch eine reiche Ausstattung oder durch eine weniger häufige Herrichtung der Grabgrube aus. Nach Frolík-Smetánka 2014.

Jak se vymezovaly/dělily další části hradní komunity, je nejisté. Snad je možné uvažovat o tom, že křest’ané byli pohřbíváni u kostela P. Marie, ale v tomto př́ípadě by dělicí čára jistě šla např́ič jednotlivými částmi/skupinami hradní komunity. Nálezy (chudší spektrum) i uspořádání naznačují rozdíl mezi pohřebišti v Lumbeho zahradě (Z-JÍZ) a u Jízdárny (V-JíZ). U ostatních je překážkou torzovité dochování a možná nereprezentativnost dochovaného vzorku. Pokud bychom od tohoto argumentu odhlédli, bylo by pohřebiště v Jelení ulici (JEL-LZ) bohatší než to u Jízdárny. Bohatší by nejspíše bylo také pohřebiště v Královské zahradě (KZ), z něhož jsou doloženy ostruhy a gombík, které se u Jízdárny a v Jelení ulici nenašly. Hypoteticky můžeme sestavit pořadí pohřebišt' podle bohatosti výbavy takto: Lumbeho zahrada Královská zahrada - Jelení ulice - Jízdárna, což snad odráží i sociální postavení skupin, jež na nich pohřbívaly. Spíše na přední místo v pořadí patří také skupina hrobů v okolí monolitu na III. nádvoří (IIIN). Mimo pořadí zůstává pohřebiště na II. nádvoří (IIN), protože téměř absolutní absence nálezů nedovoluje určitější závěry s výjimkou již zmíněné skutečnosti, že by mělo jít o křest’any. Ostatní pohřebiště, která jsme porovnávali, spíše souvisí se satelitními sídlišti širšího zázemí Pražského hradu (Prašný most/Milady Horákové, Střešovice-Triangl).

\section{Hypotéza pro izotopovou analýzu}

Při snaze postoupit dále při výzkumu jednotlivých skupin pohřbívajících na jednotlivých pohřebištích je nezbytné obrátit se k př́rodním vědám. Lákavou možností je izotopová analýza stravy pohřbených. Proto byly na pěti pohřebištích (II. nádvoří, III. nádvoří - skupina u monolitu, Lumbeho zahrada, Milady Horákové/Prašný most, Střešovice-Triangl) odebrány př́slušné vzorky a byla formulována hypotéza o očekávané kvalitě stravy. Kvalitní stravu s vysokým podílem živočišných proteinů je možno očekávat na pohřebišti Lumbeho zahrada (podle archeologické analýzy 
zde pohřbívali členové knížecí družiny a jejich rodinní př́slušníci) a u monolitu na III. nádvoří (především hrob „bojovníka“). Na pohřebišti u kostela II. nádvoří (okolí kostela P. Marie) lze také očekávat kvalitní stravu s vysokým podílem proteinů a s ohledem na předpokládanou přítomnost křest’anů doklady konzumace ryb. Naopak pohřebiště Stř̌š̌ovice-Triangl a Milady Horákové/ Prašný most náleží spíše k vesnickému zázemí. Proto byl očekáván homogenní soubor dat s nízkou variabilitou a nižším zastoupením proteinů ve stravě.

\section{Základní principy izotopové analýzy výživy}

Analýza stabilních izotopů se zejména v období po roce 2000 stala nedílnou součástí bioarcheologického výzkumu minulých populací. Největší výhodou analýzy stabilních izotopů prvků obsažených v organické (kolagen) či anorganické složce kostní tkáně je, že umožňuje získat informace o výživě konkrétních jedinců. Tato analýza je tedy vhodným doplňkem tradičních pramenů poznání výživy minulých populací, které nám přináší archeozoologie či paleobotanika, protože na rozdíl od výše zmíněných umožňuje studovat variabilitu výživy v rámci sledovaného souboru ve vztahu k biologickým (pohlaví, dožitý věk, zdravotní stav), ale i socio-ekonomickým či náboženským faktorům (např. Kjellström a kol. 2009; Reitsema-Vercellotti 2012; Rutgers a kol. 2009).

Pro rekonstrukci výživy minulých populací jsou použivány zejména poměry stabilních izotopů dusíku $\left(\delta^{15} \mathrm{~N}\right)$ a uhlíku $\left(\delta^{13} \mathrm{C}\right)$. Cyklus těchto prvků v ekosystému podléhá zákonitostem globálních geochemických procesů a umožňuje nám tak z izotopových hodnot změřených v kosti či zubu získat informace o prostředí, v němž daný jedinec žil, a o potravě, kterou konzumoval. Konkrétně nám prozrazují pozici jedince $\mathrm{v}$ potravním řetězci. V př́ípadě lidí to znamená, že jsme schopni zjistit podíl živočišných proteinů (masa a mléka) v jídelníčku. Dále nám stabilní izotopy umožňují odhalit význam konzumace ryb či roli rostlin se specifickou fotosyntetickou drahou (např. kukuřice a v našich podmínkách pak zejména prosa) ve výživě jedinců i populací (Katzenberg 2007; Lee-Thorp 2008).

Protože izotopová data se mění v čase i prostoru v reakci na řadu př́rodních, ale i antropogenních faktorů (pro podrobnější informace k tomuto tématu viz Reitsema a kol. 2013), je pro celkovou charakteristiku stravy a zejména pro srovnání s dalšími populacemi nezbytné doplnění souboru o data získaná ze zviŕecích kostí, která by optimálně měla zahrnovat hlavní hospodářsky využívané druhy na dané lokalitě (nebo v prŕípadě, že toto není možné, na lokalitě časově i geograficky blízké), včetně alespoň několika vzorků ryb.

\section{Metodika výzkumu}

Strategie vzorkování se mírně lišila mezi jednotlivými pohřebišti, a to vzhledem k rozdílné zachovalosti kosterních pozůstatků, ale i rozdílnému charakteru pohřbívání a celkové velikosti souboru. Základními kritérii pro zahrnutí do souboru bylo dosažení dospělého věku a úspěšné určení pohlaví za pomoci antropologických metod. Vzhledem k často značné neúplnosti nálezů zejména z nejstarších výzkumů pohřebišt' na II. a III. nádvoří jsme pro účely této studie považovali za dospělé všechny jedince, u nichž bylo možno pozorovat alespoň jednu kost s uzavřenou epifyzární růstovou štěrbinou. Důvodem k vyřazení nedospělých jedinců ze souboru je dosud otevřená diskuse o vlivu fyziologických (např. pozitivní dusíková bilance v průběhu růstu) a patologických procesů (vycházejících např. z nutriční deficience) na izotopové hodnoty nedospělých jedinců (pro detailní informace k tématu viz např. Reitsema 2013). Přestože tyto otázky jsou stále předmětem diskuse, je nepochybné, že výrazně rychlejší tempo kostní remodelace u nedospělých jedinců způsobuje, že izotopové hodnoty jejich kostních vzorků mohou odrážet krátkodobé události, jako je nutriční deficience nebo konzumace sezónních potravin v období nedlouho před smrtí (Beaumont a kol. 2013). Už proto je tedy nemožné porovnávat jejich hodnoty s hodnotami dospělých jedinců, jejichž kostní vzorky reflektují průměrné charakteristiky stravy za období několika desetiletí (Hedges a kol. 2007). 
Přestože nebyly pozorovány fyziologicky podložené rozdíly v izotopových hodnotách mezi pohlavími (Nitsch a kol. 2010), nelze vyloučit rozdíly definované odlišnou kvalitou konzumované stravy. V řadě středověkých populací byly pozorovány rozdíly ve výživě mezi pohlavími, které jsou vysvětlovány bud' vyšší mobilitou jednoho z pohlaví (at' už díky aplikované strategii postmaritární rezidence či díky pohlavně specifické dělbě práce) nebo lepším př́ístupem jednoho z pohlaví ke kvalitním potravním zdrojům (např. Kaupová a kol. 2014; Kjellström a kol. 2009; Reitsema-Vercellotti 2012). Až na výjimky (viz níže) byli proto vzorkováni pouze jedinci s určeným pohlavím.

Pro analýzu stabilních izotopů byl u vybraných jedinců odebrán vzorek kompaktní kostní tkáně. Přednostním místem odběru byla žebra, případně těla metakarpálních/metatarzálních kostí či článků prstů. Šlo tedy o části skeletu, které mají při antropologickém zpracování nízkou výpovědní hodnotu.

Hodnoty stabilních izotopů uhlíku a dusíku byly měřeny ve vzorku kolagenu, extrahovaného metodou dle Longina (1971) v modifikaci dle Bocherense (1992). Izotopová měření byla provedena v Iso-Analytical Limited, Crewe (UK), pomocí Europa Scientific EA a Europa Scientific 20-20 IRMS, s deklarovanou chybou měření menší než 0,1 \%o jak pro uhlík, tak pro dusík.

\section{Studovaný materiál a současný stav výzkumu}

Jádro současného výzkumu výživy populace Pražského hradu představuje pět z výše zmíněných pohřebišt': II. nádvoří, III. nádvoří - skupina u monolitu, Lumbeho zahrada, Milady Horákové/Prašný most, Střešovice-Triangl. Tato pohřebiště byla zvolena jednak s ohledem na stav zachovalosti kosterních pozůstatků, jednak ve snaze o zachycení co nejúplnějšího obrazu reálné sociální struktury sledované populace.

Nutnost kompromisů mezi těmito dvěma požadavky si vyžádala několik odchylek od výše zmíněných kritérií pro zahrnutí do analyzovaného souboru: Od kritéria dospělého věku jsme se odchýlili v prrípadě pohřebiště v ulici Milady Horákové, kde značnou část z již tak nízkého počtu pohřbených mužského pohlaví představovali jedinci ve věku 16-20 let. Vzhledem k tomu, že u jedinců v této věkové kategorii nebyl pozorován vliv růstu na hodnoty stabilních izotopů v kostní tkáni (Waters-Rist-Katzenberg 2010), považujeme pravděpodobnost zkreslení dat za relativně nízkou.

V dalších případech jsme byli nuceni upustit od kritéria určeného pohlaví, a to u několika hrobů z II. a III. nádvoří, kde charakter pohřbívání spolu s povahou archeologických výzkumů ve 30. letech zapříčinil, že dochovaný osteologický materiál často zahrnoval pouze několik málo kostí, na jejichž základě nebylo možno provést pohlavní diagnostiku. Při již tak nízkém počtu hrobů, které bylo možno chronologicky přesně zařadit do námi studovaného období, jsme proto analyzovali všechny dospělé jedince, přestože jsme si vědomi př́ípadného zkreslení výsledků při potenciálním nerovnoměrném zastoupení obou pohlaví. Toto bude dále diskutováno při interpretaci dat.

I přesto činil konečný počet vzorků z II. nádvoří pouze osm jedinců, což je dáno zejména nejistou datací většiny hrobů. V př́ípadě skupiny hrobů u monolitu se předpokládá vzorkování přibližně deseti jedinců, dosud však byl analyzován pouze vzorek kostní tkáně z hrobu „bojovníka“. Kompletně jsou dokončeny izotopové analýzy pohřebišt’ Střešovice-Triangl (19 vzorků) a Milady Horákové/Prašný most (31 vzorků - Kaupová 2016).

$\mathrm{V}$ př́ípadě pohřebiště v Lumbeho zahradě byla situace komplikována chemickou konzervací kosterního materiálu $\mathrm{v} 70$. letech, kdy byly kosti rutinně ošetřovány ponořením do roztoku metylmetakrylátu. Před vlastním výzkumem bylo tedy nutno ověřit vliv této konzervační metody na izotopové hodnoty vzorků a zvolit optimální způsob odstranění zbytků metylmetakrylátu. Proto z rozsáhlého plánovaného souboru 60 jedinců bylo doposud úspěšně analyzováno pouze deset vzorků (Kaupová 2016). V dalším průběhu práce kromě dokončení analýz na daných lokalitách předpokládáme doplnění asi 20 vzorků z pohřebiště u Jízdárny, čímž bude v našem souboru zachyceno v nejvyšší možné míře předpokládané sociální rozvrstvení populace Pražského hradu. 
Z plánovaného kontrolního souboru zvířat bylo doposud analyzováno deset vzorků z II. nádvoří zahrnujících skot (Bos taurus), prase domácí (Sus scrofa domestica), ovci/kozu (Ovis aries/Capra hircus), drůbež (Gallus domesticus) a koně (Equus caballus). Další rozšíření souboru zvírat (zejména ryb) bude však v budoucnu nezbytné. Vzhledem k elitnímu prostředí Pražského hradu by bylo vhodné analyzovat i určitý počet vzorků lovné zvěře.

\section{Předběžné výsledky výzkumu}

I když doposud malý počet vzorků analyzovaných zvířat nabádá k opatrnosti při interpretaci, zjištěné hodnoty $\left(\delta^{15} \mathrm{~N}=6,1 \pm 1,6 ; \delta^{13} \mathrm{C}=-21,0 \pm 0,5\right)^{6,7}$ odpovídají suchozemskému ekosystému založenému na $\mathrm{C}_{3}$ rostlinách. Tyto hodnoty se zároveň shodují s daty zjištěnými v případě velkomoravských Mikulčic (Kaupová a kol. 2014), což umožňuje bezprostřední srovnání dat z obou lokalit. Stejně jako v Mikulčicích ani u zvířat konzumovaných na Pražském hradě nebylo součástí krmiva proso, což má význam pro další interpretaci lidských hodnot.

V př́ípadě souboru 69 doposud analyzovaných lidských vzorků lze obecně charakterizovat stravu populace jako suchozemskou s variabilním podílem živočišných proteinů (obr. 11). Hodnoty stabilních izotopů uhlíku $\left(\delta^{13} \mathrm{C}=-18,9 \pm 0,6\right)^{8}$ jsou na populační úrovni na hranici prokazatelné konzumace $\mathrm{C}_{4}$ rostlin (Fuller a kol. 2012; Le Huray-Schutkowski 2005). Tato hranice se v podání různých autorů pohybuje mezi $-19 \% \mathrm{a}-18 \%$. V našem souboru nalezneme jedince s hodnotami bezesporu za touto hranicí, ale na druhé straně i takové, jejichž strava se jeví být založena čistě na $\mathrm{C}_{3}$ rostlinách. To je na první pohled rozdílné ve srovnání s populací Velké Moravy, kde bylo proso prokazatelně konzumováno nejen ve venkovském prostředí, ale i v rámci populace mikulčického centra, a to bez ohledu na socio-ekonomické postavení jedince (Kaupová a kol. 2014). Možné vysvětlení tohoto jevu lze spatřovat v klimatických podmínkách. Proso jako teplomilná a suchovzdorná rostlina (Konvalina-Moudrý-Kalinová 2007; Moudrý 2005) mohlo mít ideální podmínky právě v podnebí jižní Moravy. I když jeho nálezy jsou známy i z raně středověkých Čech, na lokalitách z 9.-10. století je charakteristická dominance pšenice (zejména Triticum aestivum) a role prosa se zdá být pouze marginální (Kočár a kol. 2010).

Strava obyvatel Pražského hradu se - přinejmenším co se týče izotopových charakteristik - mnohem více podobala stravě obyvatel polského Giecze 11.-12. století (Reitsema-CrewsPolcyn 2010). Zda je možné tento trend vysvětlit pouze klimatickými rozdíly, nebo zda může jít o doklad chronologických změn v potravním chování obyvatelstva např. v souvislosti s intenzifikací zemědělské produkce (Kočár a kol. 2010), bude předmětem dalšího výzkumu.

I přestože zatím nebyly analyzovány kosti ryb, a je tedy nutno lidská data v tomto směru interpretovat s nejvyšší opatrností, zdá se, že ryby netvořily důležitou součást výživy dané populace - až na potenciálně jedinou výjimku, která bude diskutována dále. Absence ryb v jídelníčku je znak, který populaci Pražského hradu spojuje s populací velkomoravských Mikulčic, i přes bezprostřední blízkost vodních toků, které představovaly bohaté zdroje potenciálních úlovků. Jak ale ukazují izotopová data z jiných oblastí Evropy, zjevná dostupnost ryb neznamená vždy automaticky, že ryby tvořily podstatnou část jídelníčku (např. Barrett-Richards 2004; Eriksson a kol. 2008; Le Bras-Goude a kol. 2013).

Pokud sledujeme hodnoty v rámci jednotlivých pohřebišt', můžeme pozorovat rozdíly mezi lokalitami, které svědčí o pokročilé sociální diferenciaci v rámci populace Pražského hradu a jeho bezprostředního okolí. Analýza potenciálního vztahu mezi izotopovými charakteristikami výživy a jednotlivými atributy socio-ekonomického postavení na individuální úrovni, jako je přítomnost a kvalita hrobové výbavy, rozměry hrobu či jeho úprava s pomocí dřevěné či kamenné konstrukce, bude předmětem dalšího výzkumu a pro tuto chvíli zůstaneme u srovnání mezi jednotlivými lokalitami a jejich socio-ekonomickou charakteristikou, stanovenou na základě archeologických dat.

6 Po vyloučení drůbeže; hodnoty drůbeže se ve shodě s dalšími studiemi vydělují ze souboru ostatních zvířat a výrazně se podobají lidským hodnotám, což je důsledkem chovu drůbeže v blízkosti domácnosti a stravou přinejmenším zčásti založenou na zbytcích lidských pokrmů a dalších odpadcích (Reitsema et al. 2013).

7 Průměr \pm SD

8 Průměr \pm SD 


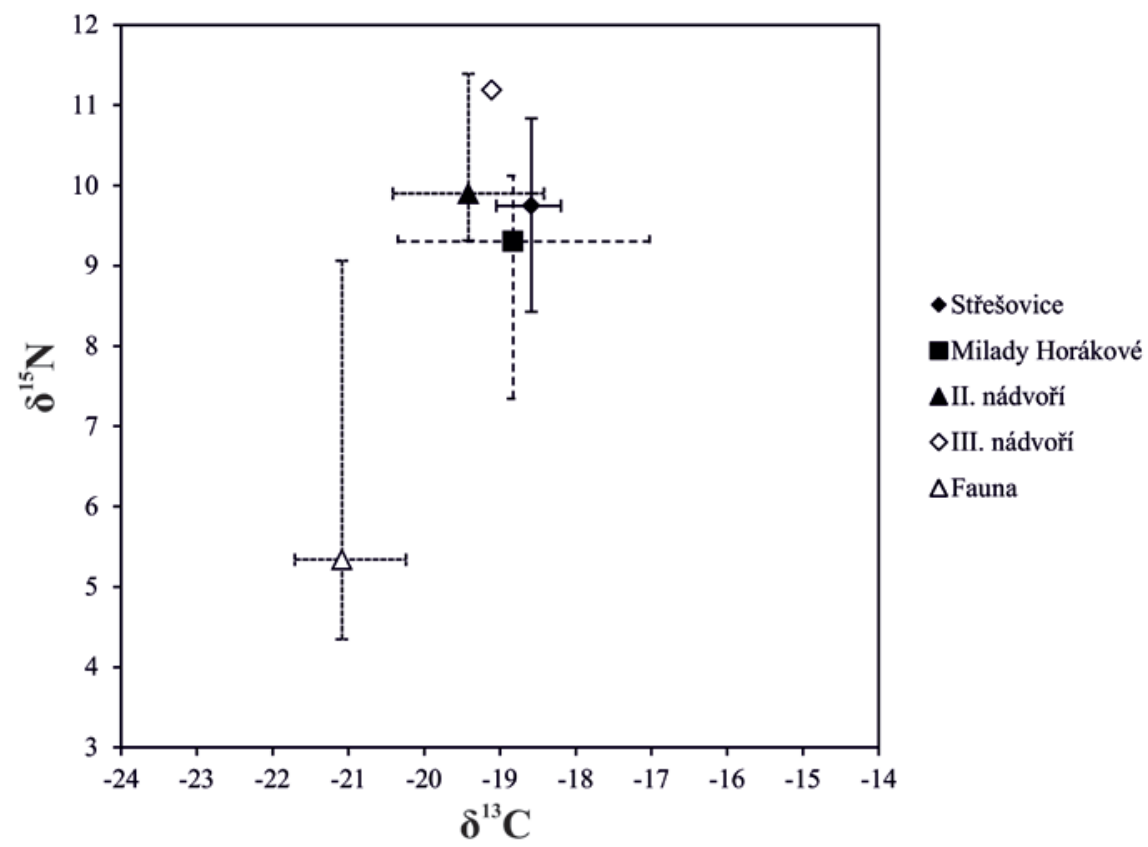

Obr. 11. Izotopové hodnoty souboru z Pražského hradu a jeho zázemí (medián, minimum, maximum).

Abb. 11. Isotopenwerte der Gruppe von der Prager Burg und ihres Hinterlandes (Median, Minimum, Maximum).

Na lokalitě Střešovice-Triangl zjištěná data o výživě odpovídají předpokládanému venkovskému charakteru souboru jak nízkou variabilitou dat, tak nízkým podílem živočišných proteinů ve stravě, který je srovnatelný s venkovským souborem z velkomoravského Josefova (Kaupová a kol. 2014).

Jako doposud největší překvapení se jeví výsledky z pohřebiště v ulici Milady Horákové. Přestože zde byl předpokládán obdobný (případně mírně vyšší) socio-ekonomický status jako v př́ípadě Střešovic, izotopové hodnoty se mezi oběma soubory na první pohled liší: Hodnoty stabilních izotopů dusíku jsou zde v průměru nižší než na lokalitě Střešovice-Triangl a v případě uhlíku jsou data nejen v průměru odlišná, ale i mnohem více variabilní. Na rozdíl od Střešovic zde pozorujeme významný rozdíl mezi hodnotami mužů a žen. Přitom muži překvapivě vykazují v průměru nižší hodnoty jak pro uhlík, tak pro dusík. Zatímco většina žen vykazuje stravu podobnou střešovickému souboru (i když hodnoty stabilních izotopů uhlíku jsou i zde nižší, nenacházíme hodnoty nad 10,5 \%o), mužské hodnoty se liší mnohem výrazněji. Izotopová data jsou tedy dalším dokladem, který spolu s atypickou demografickou strukturou souboru ukazuje na specifické postavení skupiny obyvatel pohřbívající na lokalitě Milady Horákové. Příčiny tohoto jevu budou předmětem dalšího výzkumu.

Naopak hodnoty zjištěné v souboru na II. nádvoří a v př́ípadě hrobu bojovníka potvrzují předpoklad velmi kvalitní stravy s vysokým podílem živočišných proteinů. Zejména v porovnání se souborem z lokality Střešovice-Triangl svědčí kombinace vyšších hodnot pro dusík spolu s nižšími hodnotami uhlíku pro možné podstatnější zastoupení ryb v jídelníčku, což by bylo v souladu s křest’anským charakterem pohřebiště na II. nádvoří. Nicméně ve srovnání s populacemi s významnou závislostí na sladkovodních rybách nelze považovat vyšší konzumaci ryb za prokázanou (Katzenberg-Weber 1999; Rutgers a kol. 2009). Více světla do této otázky mohou vnést výsledky budoucí izotopové analýzy kostí ryb.

Při analýze dat z II. nádvoří je však nutné vzít v potaz možné ovlivnění celkové charakteristiky stravy na II. a III. nádvoří odlišným zastoupením mužů a žen. Například ve velkomoravských Mikulčicích byly pozorovány mezipohlavní rozdíly ve stravě právě v prostředí elitních vrstev, 
rozpoznaných na základě hrobové výbavy (Kaupová a kol. 2014). S mírně vyšší jistotou se tak budeme moci vyjádřit o stravě elitních vrstev, teprve až budeme mít k dispozici kompletní výsledky z ostatních lokalit, které nám ukážou, zda byly pohlavně determinované rozdíly ve výživě ve sledované populaci běžné, či zda v př́ípadě lokality Milady Horákové šlo o ojedinělý případ, který pouze podtrhuje jedinečnost tohoto nálezového celku.

První výsledky z pohřebiště v Lumbeho zahradě kladou tuto skupinu obyvatel z hlediska výživy na pomezí mezi venkovskou komunitu z lokality Střešovice-Triangl a elitní skupinu z II. nádvoří. Vzhledem $\mathrm{k}$ tomu, že byl doposud analyzován pouze zlomek z plánovaného počtu jedinců, však jde pouze o předběžné sdělení.

\section{Závěr}

Pokud pomineme výsledky z Lumbeho zahrady, kde by v této fázi výzkumu byla jakákoliv interpretace dat zavádějící, lze říci, že ve většině sledovaných případů odpovídala strava na jednotlivých pohřebištích předpokládanému socio-ekonomickému postavení, definovanému na základě archeologických indikátorů. Výjimkou z tohoto trendu je pohřebišsě v ulici Milady Horákové, kde izotopová data spolu s dalšími antropologickými nálezy ukazují na existenci specifické, pravděpodobně silně diferencované skupiny obyvatel, kterou nebylo možno v archeologickém záznamu rozpoznat (tab. 1).

\begin{tabular}{|c|c|c|c|c|c|}
\hline Pohřebiště & $\begin{array}{l}\text { Archeologická } \\
\text { interpretace }\end{array}$ & Počet vzorků & $\begin{array}{c}\text { Strava na základě analýzy } \\
\text { izotopů stravy }\end{array}$ & Srovnání & Poznámka \\
\hline Lumbeho zahrada & $\begin{array}{l}\text { Členové knížecí } \\
\text { družiny a jejich } \\
\text { rodinní příslušníci }\end{array}$ & 10 & $\begin{array}{l}\text { Kvalitní výživa s vysokým } \\
\text { podílem živočišných proteinů }\end{array}$ & $+/-$ & $\begin{array}{l}\text { Prozatím malý } \\
\text { vzorek s velkým } \\
\text { rozptylem dat }\end{array}$ \\
\hline $\begin{array}{l}\text { III. nádvoři / } \\
\text { bojovník - hrob } \\
\text { IIIN199 }\end{array}$ & Příslušník elity & 1 & $\begin{array}{l}\text { Kvalitní výživa s vysokým } \\
\text { podilem živočišným proteinů }\end{array}$ & + & \\
\hline $\begin{array}{c}\text { II. nádvoří- } \\
\text { u kostela P. Marie }\end{array}$ & $\begin{array}{l}\text { Kostelní pohřebiště } \\
=\text { křest'ané, vyšši } \\
\text { sociální status }\end{array}$ & 8 & $\begin{array}{c}\text { Kvalitní výživa s vysokým } \\
\text { podílem živočišných proteinů, } \\
\text { konzumace ryb }\end{array}$ & + & \\
\hline Střešovice-Triangl & $\begin{array}{l}\text { Spíše vesnické } \\
\text { zázemí }\end{array}$ & 19 & $\begin{array}{l}\text { Nižší zastoupení živočišných } \\
\text { proteinů ve stravě, homogenní } \\
\text { soubor s nízkou variabilitou dat }\end{array}$ & + & \\
\hline $\begin{array}{l}\text { Prašný most/ } \\
\text { Milady Horákové }\end{array}$ & $\begin{array}{l}\text { Spíše vesnické } \\
\text { zázemí }\end{array}$ & 31 & $\begin{array}{l}\text { Nižší zastoupení živočišných } \\
\text { proteinů, homogenní soubor } \\
\text { s nízkou variabilitou dat }\end{array}$ & $+/-$ & $\begin{array}{l}\text { V souboru vy- } \\
\text { členěna skupina se } \\
\text { specifickou stravou }\end{array}$ \\
\hline
\end{tabular}

Tab. 1. Srovnání archeologické interpretace posuzovaných pohřebišt' a výsledků analýzy izotopů stravy.

Článek vznikl za finanční podpory projektu 14-36938G „Středověká populace v centru a na venkově. Archeologie, bioarcheologie a genetika na pohřebištích Pražského hradu, středních a východních Čech" podporovaného Grantovou agenturou ČR a za finanční podpory Ministerstva kultury v rámci institucionálního financování dlouhodobého koncepčního rozvoje výzkumné organizace Národní muzeum (DKRVO 2015/19 a 2016/19, 00023272).

\section{Prameny a literatura}

BARRETT, J. H.-RICHARDS, M. P., 2004: Identity, gender, religion and economy: new isotope and radiocarbon evidence for marine resource intensification in early historic Orkney, Scotland, UK, European Journal of Archaeology 7(3), 249-271. DOI: 10.1177/1461957104056502

BEAUMONT, J. a kol., 2013: Beaumont, J.-Geber, J.-Powers, N.-Wilson, A.-Lee-Thorp, J.-Montgomery, J., Victims and survivors: stable isotopes used to identify migrants from the Great Irish Famine to 19th century London, American Journal of Physical Anthropology 150(1), 87-98.

BECKER, M. J., 2000: Human Skeletal Remains Recovered from Excavations in the Area of the Church of Virgin Mary, Prague Castle, Czech Republic. In: Frolík, J.-Maříková-Kubková, J.-Růžičková, E.-Zeman, A., 
Nejstarší sakrální architektura Pražského hradu. Výpověd' archeologických pramenů. Castrum Pragense 3, 289-354. Praha.

- 2001: Human Skeletons Excavated from a Series of "cemetery" Areas Within the Prague Castle, Czech Republic, rukopis ulož. v ARÚ AV ČR, Praha, v. v. i., pracoviště Pražský hrad.

BOCHERENS, H., 1992: Biogéochimie isotopique (13C, 15N, 18O) et paléontologie des vertébrés: applications à l'étude des réseaux trophiques révolus et des paléoenvironnements, disertační práce, Université Paris VI.

BLAJEROVÁ, M., 1992: Kostrové pozůstatky z raně středověkého pohřebiště za Jízdárnou na Pražském hradě. Antropologický posudek ulož. v archivu ARÚ AV ČR, Praha, v. v. i., sign. TP 19930042.

- 2006: Kostrové pozůstatky z pohřebiště u Jízdárny Pražského hradu - Die Skelette aus dem Gräberfeld bei der Reitschule der Prager Burg. In: Pohřbívání na Pražském hradě a jeho předpolích. Díl I.2 - Katalog. Antropologie. Castrum Pragense 7 (Tomková, K., ed.), 177-234, 280-281. Praha.

BLAŽKOVÁ-DUBSKÁ, G., 2006: Novověké pohřebiště u Jízdárny - Das neuzeitliche Gräberfeld bei der Reitschule. In: Pohřbívání na Pražském hradě a jeho předpolích. Díl I.2 - Katalog. Antropologie. Castrum Pragense 7 (Tomková, K., ed.), 145-173, 279. Praha.

BOHÁČOVÁ, I.-BLAŽKOVÁ, G., 2011: Pohřebiště na Loretánském náměstí v Praze - Hradčanech. Archeologický výzkum Ivana Borkovského a jeho výsledky - Burial Grounds at Loretánské Square in Prague - Hradčany. The archaeological excavation of Ivan Borkovský and results thereof. Castrum Pragense 11. Praha.

BORKOVSKÝ, I., 1941: Das Wikingergrab auf der Prager Burg, Altböhmen und Altmähren 1, 171-182.

- 1939-1946: Hrob bojovníka z doby knížecí na Pražském hradě - The grave of a warrior of the prince-period, PA XLII, 122-131, 221.

- 1953: Kostel Panny Marie na Pražském hradě - Kostěl Bogorodicy v Pražskom kremle - Église de la Ste Vierge au Château de Prague, PA XLIV, 129-198.

BŘEZINOVÁ, H.-TUREK, J., 1999: Šňůrové a raně středověké pohřebiště v severním předpolí Pražského hradu - archeologický výzkum v Lumbeho zahradě - The Corded Ware and early medieval cemetery in northern vicinity of Prague Castle. An archaeological excavation in the Lumbe Garden, AR LI, 653-687.

DRAGOUN, Z., 2006: Raně středověká pohřebiště na předpolí Pražského hradu II - Frühmittelalterliche Gräberfelder auf dem Vorfeld der Prager Burg II. In: Pohřbívání na Pražském hradě a jeho předpolích. Díl I.2 - Katalog. Antropologie. Castrum Pragense 7 (Tomková, K., ed.), 129-144, 279. Praha.

ERIKSSON, G. a kol., 2008: Eriksson, G.-Linderholm, A.-Fornander, E.-Kanstrup, M.-Schoultz, P.-Olofsson, H.-Lidén, K., Same island, different diet: cultural evolution of food practice on Öland, Sweden, from the Mesolithic to the Roman Period, Journal of Anthropological Archaeology 27(4), 520-543. DOI: 10.1016/j.jaa.2008.08.004

FROLÍK, J., 2005: Hroby přemyslovských knížat na Pražském hradě - Die Gräber der Přemyslidenfürsten auf der Prager Burg. In: Pohřbívání na Pražském hradě a jeho předpolích - Das Bestatten auf der Prager Burg und Ihren Vorfeldern. Díl I.1 - Textová část. Castrum Pragense 7 (Tomková, K., ed.), 25-46. Praha.

- 2013: Pohřebiště na II. nádvoří Pražského hradu - Das Gräberfeld auf dem II. Burghof der Prager Burg, AH 38, 91-105.

- 2013a: Das Gräberfeld im Lumbe-Garten auf der Prager Burg - eine Fallstudiezur Untersuchung der Sozialstruktur des 10. Jahrhunderts. In: Soziale Gruppen und Gesellschaftstrukturen im westslawischen Raum, Beoiträge zur Ur- und Frühgeschichte Mitteleuropas 70 (Biermann, F.-Kersting, T.-Klammt, A., edd.), 33-42. Langenweissbach.

- 2015: Pohřebiště na II. nádvoří Pražského hradu a u kostela Panny Marie. Díl I. Katalog. Castrum Pragense 14. Praha.

FROLÍK, J.-MAŘÍKOVÁ-KUBKOVÁ, J.-RU゚ŽIČKOVÁ, E.-ZEMAN, A., 2000: Nejstarší sakrální architektura Pražského hradu. Výpověd' archeologických pramenů - Die ältesten Kirchenbauten der Prager Burg aufgrind der archäologischen Quellen. Castrum Pragense 3. Praha.

FROLÍK, J.-SMETÁNKA, Z., 2014: Pohřebiště v Lumbeho zahradě na Pražském hradě. Díl I. Katalog. Castrum Pragense 12. Praha.

FROLÍK, J. a kol., 2014: Pohřebiště v Lumbeho zahradě na Pražském hradě. Díl II. Studie. Castrum Pragense 12. Praha.

FROLÍKOVÁ-KALISZOVÁ, D., 2014: Pohřebiště z 10. století v Praze-Střešovicích - předběžná zpráva Ein Gräberfeld aus dem 10. Jhdt. in Prag-Střešovice - vorläfiger Bericht, AH 39, 315-329.

FULLER, B. T. a kol., 2012: Fuller, B. T.-De Cupere, B.-Marinova, E.-Van Neer, W.-Waelkens, M.-Richards, M. P., Isotopic reconstruction of human diet and animal husbandry practices during the Classical-Hellenistic, imperial, and Byzantine periods at Sagalassos, Turkey, American Journal of Physical Anthropology 149(2), 157-171. DOI: 10.1002/ajpa.22100 
GALUŠKA, L., 2005: Gehörten die in der Särgen bestattenen Personen zur Gesellschaftselite des Großmährischen Staré Město - Uherské Hradiště? In: Die Frühmittelalterliche Elite bei den Völkern des östlichen Mitteleuropas. Spisy Archeologického ústavu AV ČR Brno 25 (Kourril, P., ed.), 193-207. Brno.

HEDGES, R. E. a kol., 2007: Hedges, R. E.-Clement, J. G.-Thomas, C. D.-O’Connell, T. C., 2007: Collagen turnover in the adult femoral mid-shaft: modeled from anthropogenic radiocarbon tracer measurements, American Journal of Physical Anthropology 133(2), 808-816. DOI: 10.1002/ajpa.20598

KATZENBERG, M. A., 2007: Stable isotope analysis: a tool for studying past diet, demography, and life history. In: Biological Anthropology of the Human Skeleton (Katzenberg, M. A.-Saunders, R., edd.), 411-441. Second Edition, Hoboken, NJ.

KATZENBERG, M. A.-Weber, A., 1999: Stable isotope ecology and palaeodiet in the Lake Baikal region of Siberia, Journal of Archaeological Science 26(6), 651-659. DOI: 10.1006/jasc.1998.0382

KAUPOVÁ, S., 2016: Průběžná zpráva. Analýza výživy populace Pražského hradu a jeho zázemí, ulož. v ARÚ AV ČR, Praha, v. v. i., pracoviště Pražský hrad, čj. ARUP-1299/2016.

KAUPOVÁ, S. a kol., 2014: Kaupová, S.-Herrscher, E.-Velemínský, P.-Cabut, S.-Brůžek, J., Urban and rural dietary patterns in early Medieval Central Europe (9th-10th century AD, Czech Republic). Abstract. Program of the 83rd Annual Meeting of the American Association of Physical Anthropologists, American Journal of Physical Anthropology 153, 155.

KJELLSTRÖM, A. a kol., 2009: Kjellström, A.-Storå, J.-Possnert, G.-Linderholm, A., Dietary patterns and social structures in medieval Sigtuna, Sweden, as reflected in stable isotope values in human skeletal remains, Journal of Archaeological Science 36(12), 2689-2699. DOI: 10.1016/j.jas.2009.08.007

KOČÁR, P. a kol., 2010: Kočár, P.-Čech, P.-Kozáková, R.-Kočárová, R., Environment and economy of the Early Medieval settlement in Žatec. Interdisciplinaria Archaeologica, Natural Sciences in Archaeology $1(1-2), 45-60$.

KONVALINA, P.-MOUDRÝ, J.-KALINOVÁ, J., 2007: Pěstování rostlin v ekologickém zemědělství. České Budějovice: Jihočeská univerzita v Českých Budějovicích.

KUBKOVÁ, J., 1997: Ecce lignum crucis,in quo salus mundi pependit. In: Život v archeologii středověku - Das Lebenin der Archäologie des Mittelalters - Life in the Archaeology of the Middle Ages - La vie vue par l'archéologie medievale. Papers in Honor of Miroslav Richter and Zdeněk Smetánka (Kubková, J.-Klápště, J.Ježek, M.-Meduna, P., edd.), 402-407. Praha.

LE BRAS-GOUDE, G. a kol., 2013: Le Bras-Goude, G.-Herrscher, E.-Vaquer, J., Funeral practices and foodstuff behaviour: What does eat meat mean? Stable isotope analysis of Middle Neolithic populations in the Languedoc region (France), Journal of Anthropological Archaeology 32(3), 280-287.

LE HURAY, J. D.-SCHUTKOWSKI, H., 2005: Diet and social status during the La Tene period in Bohemia: carbon and nitrogen stable isotope analysis of bone collagen from Kutná Hora-Karlov and Radovesice, Journal of Anthropological Archaeology 24(2), 135-147. DOI: 10.1016/j.jaa.2004.09.002

LEE-THORP, J. A., 2008: On Isotopes and Old Bones, Archaeometry 50(6), 925-950. DOI: 10.1111/j.1475$-4754.2008 .00441 . x$

LONGIN, R., 1971: New method of collagen extraction for radiocarbon dating, Nature 230, 241-242. DOI: 10.1038/230241a0

MOUDRÝ, J., 2005: Pohanka a proso. Praha: Ústav zemědělských a potravinářských informací.

NITSCH, E. K. a kol., 2010: Nitsch, E. K.-Humphrey, L. T.-Hedges, R. E. M., The effect of parity status on $\delta^{15} \mathrm{~N}$ : looking for the "pregnancy effect" in 18th and 19th century London, Journal of Archaeological Science 37(12), 3191-3199. DOI: 10.1016/j.jas.2010.07.019

REITSEMA, L. J., 2013: Beyond diet reconstruction: Stable isotope applications to human physiology, health, and nutrition, American Journal of Human Biology 25(4), 445-456. DOI: 10.1002/ajhb.22398

REITSEMA, L. J.-CREWS, D. E.-POLCYN, M., 2010: Preliminary evidence for medieval Polish diet from carbon and nitrogen stable isotopes, Journal of Archaeological Science 37(7), 1413-1423. DOI: 10.1016/j.jas.2010.01.001

REITSEMA, L. J.-VERCELLOTTI, G., 2012: Stable isotope evidence for sex-and status-based variations in diet and life history at medieval Trino Vercellese, Italy, American Journal of Physical Anthropology 148(4), 589-600. DOI: 10.1002/ajpa.22085

REITSEMA, L. a kol., 2013: Reitsema, L.-Kozłowski, T.-Makowiecki D., Human-environment interactions in medieval Poland: a perspective from the analysis of faunal stable isotope ratios, Journal of Archaeological Science 40(10), 3636-3646. DOI: 10.1016/j.jas.2013.04.015

RUTGERS, L. a kol., 2009: Rutgers, L.-Van Strydonck, M.-Boudin, M.-Van der Linde, C., Stable isotope data from the early Christian catacombs of ancient Rome: new insights into the dietary habits of Rome's early Christians, Journal of Archaeological Science 36(5), 1127-1134. DOI: 10.1016/j.jas.2008.12.015 
SKLENÁŘ, K.-SLÁMA, J., 1976: Nález slovanských kostrových hrobů v bývalé Královské zahradě Pražského hradu v roce 1837 - Die Entdeckung slawischer Körpergräber im Königlchen arten der Prager Burg im J. 1837, AR XXVIII, 659-665, 720.

SMETÁNKA, Z., 1988: Stopa magického jednání na pohřebišti za Jízdárnou Pražského hradu - A trace of magical procedure on the Early Mediaeval cemetery behind the Riding School of Prague Castle, Sborník Kruhu přátel Muzea hl. m. Prahy 1, 94-107.

SOMMER, P., 1985: Hradištní pohřebiště v premonstrátské kanonii na Strahově - Das Burwall-Gräberfeld im Prämonstratenser Kanonikat in Prag-Strahov, Sborník Národního muzea v Praze - Acta Musei Nationalis Pragae 39, č. 3-4, 193-197.

STRÁNSKÁ, P., 2013: Antropologický posudek č. 1142, ulož. v archivu ARÚ AV ČR, Praha, v. v. i., sign. TP 20132608.

- 2014: Antropologická analýza lidských kostrových pozůstatků z raně středověkého pohřebiště v Praze-Střešovicích, poloha Triangl - Anthropologische Analyse menschlicher Skelettüberreste von dem frühmittelalterlichen Gräberfeld in Prag-Střešovice, Lage Triang1, AH 39, 69-83.

TOMKOVÁ, K., 2005a: Hmotná kultura raně středověkých pohřebišt’ Pražského hradu a jeho předpolí - Das Grabinventar auf den frühmittelalterlichen Gräberfeldern der Prager Burg und Ihrer Volferder. In: Pohřbívání na Pražském hradě a jeho předpolích. Díl I.1 - Textová část. Castrum Pragense 7 (Tomková, K., ed.), 217-304. Praha.

- 2013: Urbs Praga und Levý Hradec - von Sklaven zu Fürsten. In: Soziale Gruppen und Gesellschaftstrukturen im westslawischen Raum. Beoiträge zur Ur- und Frühgeschichte Mitteleuropas 70 (Biermann, F.Kersting, T.-Klammt, A., edd.), 43-55. Langenweissbach.

- 2015: Nálezová zpráva o záchranném archeologickém výzkumu. Akce: Pražský hrad - Královská zahrada, Královský letohrádek - oprava př́ivodních kabelů vč. výměny skříní, č. IDAV 51350, ulož. v archivu ARÚ AV ČR, Praha, v. v. i., sign. TX-2015-2258.

TOMKOVÁ, K., ed., 2005: Pohřbívání na Pražském hradě a jeho předpolích - Das Bestatten auf der Prager Burg und ihren Vorfeldern. Díl I.1 - Textová část. Castrum Pragense 7. Praha.

- 2006: Pohřbívání na Pražském hradě a jeho předpolích - Das Bestatten auf der Prager Burg und Ihren Vorfeldern. Díl I.2 - Katalog. Antropologie. Castrum Pragense 7. Praha.

TOMKOVÁ, K.-FROLÍK, J., 2005: Topografie pohřebišt' v areálu Pražského hradu a na jeho předpolích Die Topographie der Bestattungen im Areal der Prager Burg und auf ihren Vorfelden. In: Pohřbívání na Pražském hradě a jeho předpolích. Díl I.1. Castrum Pragense 7 (Tomková, K., ed.), 7-24. Praha.

WATERS-RIST, A. L.-KATZENBERG, M. A., 2010: The effect of growth on stable nitrogen isotope ratios in subadult bone collagen, International Journal of Osteoarchaeology 20(2), 172-191.

\section{Zusammenfassung}

\section{Die Gräberfelder der Prager Burg und Möglichkeiten ihrer sozialen Interpretation}

Die Prager Burg ist ein über einen langen Zeitraum archäologisch untersuchtes Objekt, bei welchem vom Ende des 9. und aus dem 10. Jahrhundert stammende Gräberfelder einen wichtigen Teil der Funde darstellen (Abb. 1). Der überwiegende Teil wurde in Katalogform veröffentlicht (Königsgarten [KZ], Reithalle [V-JÍZ], Lumbe-Garten [Z-JíZ], Hirschstraße [JEL-LZ], Umgebung der Marienkirche [IIN]). Das Gräberfeld Střešovice-Triangl (SC) ist vorläufig zugänglich. Unvollständige Informationen sind über das Gräberfeld Pulverbrücke (PM) verfügbar. Vom III. Burghof sind Angaben über eine Gruppe von in der Umgebung des Granitmonoliths befindlichen Gräbern verwertbar. Demzufolge kann untersucht werden, ob sich die Gräberfelder hinsichtlich Ausstattung und Anordnung voneinander unterscheiden. Das Gräberfeld im Lumbe-Garten wurde als einziges in seiner Gesamtheit untersucht (148 Gräber; Abb. 2). Torsohafte Erkenntnisse liegen bezüglich dem auf der Grenze zwischen Lumbe-Garten I und der Hirschstraße befindlichen Gräberfeld vor (JEL-LZ, 16 Gräber). Das Gräberfeld an der Reithalle (V-JíZ) umfasst 66 frühmittelalterliche Gräber. Neu erforscht wurde der letzte Teil des mit der verschwundenen Strahover Ziegelei zusammenhängenden Gräberfeldes mit 49 Gräbern (SC; Abb. 4). Auf dem Gräberfeld Pulverbrücke (Milada Horáková-Str. - PM) wurden insgesamt 83 Gräber untersucht (Abb. 5). Auf dem III. Burghof (IIIN) entdeckte man insgesamt 245 
Gräber, und zwar einschließlich der Gruppe von 13 Gräbern im Westteil des III. Burghofs in der Umgebung des Granitmonoliths. Das Gräberfeld auf dem II. Burghof mit der Marienkirche (Abb. 6) zählt 81 Gräber. Die Anzahl der Kindergräber bewegt sich zwischen 11 und 58,8 \%. Eine geringe Anzahl an Kindergräbern wurde bei den nur torsohaft erhalten gebliebenen Gräberfäldern entdeckt (JEL-LZ, IIIN). Ein übliches Vorkommen wurde von uns auf dem Gräberfeld Střešovice-Triangl (SC - 46,2 \%) und im Lumbe-Garten (44,8 \%) festgestellt. Mehr Kinderbestattungen sind im II. Burghof belegt (IIN - 54,5 \%). Das höchste Vorkommen (58,8 \%) wird auf dem Gräberfeld Pulverbrücke verzeichnet. Bemerkenswert ist die Repräsentanz der Männer- und Frauenbestattungen. Ein ausgeglichenes Verhältnis konnte auf dem III. Burghof, auf dem II. Burghof sowie auf dem Gräberfeld Střešovice-Triangl festgestellt werden. Die im nahegelegenen Burghinterland befindlichen Gräberfelder (V-JÍZ, JEL-LZ, Z-JÍZ) weisen einen hohen Frauenanteil auf (insgesamt 70,3\%).

Bei den Überlegungen über die jeweilige Stellung eines konkreten Individuums dienten die Funde am häufigsten als Grundlage (Liebesgaben, Grabbeigaben). Die reichsten Ausstattungen wurden bei Personen festgestellt, die auf dem Gräberfeld im Lumbe-Garten bestattet wurden (Knöpfe, traubenförmige Ohrringe, trommelförmige Ohrringe, Kaptorgen, Äxte). Eine Luxuswaffe war das nur in einem einzigen Grab (IIIN199) direkt im Areal der Prager Burg belegte Schwert. Auf dem Gräberfeld im Lumbe-Garten wurden insgesamt 33 Gräber ausgemacht, die eine reiche Ausstattung hatten, bzw. welche die Bedeutung der Bestatteten andeuteten (Abb. 10). Auf allen übrigen Gräberfeldern wurden lediglich sieben solcher Gräber erfasst (davon drei auf dem Gräberfeld Střešovice-Triangl; zwei bei der Reithalle und zwei auf dem III. Burghof in der Gruppe bei dem Granitmonolith). Auffallend dabei ist, dass Frauengräber unter ihnen die Mehrheit stellen. Die auf der Prager Burg lebende Gemeinschaft war in ihrem Innern differenziert, was sich daran zeigt, dass ein Teil von ihr über einen längeren Zeitraum ausschließlich (?) im Lumbe-Garten Bestattungen durchführte, während die übrigen Teile dies auf anderen (ihren?) Gräberfeldern taten. Es ist wahrscheinlich, dass die Christen an der Marienkirche beigesetzt wurden. Die entsprechend der Reichhaltigkeit der Ausstattung folgendermaßen vorgenommene Abstufung Lumbe-Garten - Königsgarten - Hirschstraße - Reithalle spiegelt wohl auch die soziale Stellung der dort bestatteten Gruppen wider. Das Gräberfeld auf dem II. Burghof (IIN) bleibt bei dieser Abstufung außen vor, da das Fehlen von Funden keine bestimmteren Schlussfolgerungen zulässt, mit Ausnahme der Tatsache, dass es sich bei den dort Bestatteten um Christen handeln dürfte. Die übrigen Gräberfelder hängen mit den Satellitensiedlungen des weiteren Hinterlandes der Prager Burg zusammen (Pulverbrücke/Milada Horáková-Str., Stř̌ešovice-Triangl).

Bei der Bemühung, die Erforschung der einzelnen Bestattungsgruppen auf den jeweiligen Gräberfeldern voranzutreiben, kommt man nicht umhin, sich an die Naturwissenschaften zu wenden. Dabei ist die Isotopenanalyse der Nahrung der Bestatteten eine verlockende Möglichkeit. Aus diesem Grunde hat man auf fünf Gräberfeldern (II. Burghof, III. Burghof - Gruppe am Granitmonolith, Lumbe-Garten, Milada Horáková-Str./Pulverbrücke, Střešovice-Triangl) Proben entnommen und eine Hypothese über die zu erwartende Qualität der Nahrung formuliert. Um die Ernährung der vergangenen Populationen rekonstruieren zu können, wurden besonders die Verhältnisse der stabilen Isotope Stickstoff $\left(\delta^{15} \mathrm{~N}\right)$ und Kohlenstoff $\left(\delta^{13} \mathrm{C}\right)$ herangezogen. Konkret verraten diese uns die jeweile Position eines Individuums in der Nahrungskette. Im Falle von Menschen bedeutet dies, dass wir dazu in der Lage sind, den Anteil der tierischen Proteine (Fleisch und Milch) im Speiseplan festzustellen. Ferner ermöglichen die stabilen Isotope es uns, die Bedeutung des Verzehrs von Fisch oder die Rolle der Pflanzen mit photosynthetischem Weg zu erschließen (z.B. von Hirse). Für die Analyse stabiler Isotopen wurde bei ausgewählten Individuen eine Probe vom kompakten Knochengewebe entnommen. Bevorzugte Entnahmestelle waren die Rippen, ggf. die Mittelhand-/Mittelfußknochen oder die Fingerglieder. Die Werte der stabilen Isotope Kohlenstoff und Stickstoff wurden anhand einer Kollagenprobe bestimmt, die mittels einer Kollagen-Gelatine-Extraktion nach Longin (1971) modifiziert von Bocherens (1992) gewonnen wurde. Die Isotopenmessungen wurden im Labor der Firma Iso-Analytical Limited (Crewe, UK) unter Verwendung der Geräte Europa Scientific EA und Europa Scientific 
20-20 IRMS bei einer deklarierten Messabweichung von weniger als 0,1 \%o sowohl für Kohlenstoff als auch für Stickstoff durchgeführt.

Folgende fünf oben genannte Gräberfelder bilden den Kern der gegenwärtigen Erforschung der Ernährung der Population der Prager Burg: II. Burghof, III. Burghof - Gruppe am Granitmonolith, Lumbe-Garten, Milada Horáková-Str./Pulverbrücke, Střešovice-Triangl. Die Anzahl der Proben vom II. Burghof betraf lediglich acht Individuen. Von der Grabgruppe am Granitmonolith wurde vorerst lediglich eine Knochengewebsprobe aus dem Grab des „Kriegers“ analysiert. Komplett abgeschlossen sind die Isotopenanalysen der Gräberfelder Střešovice-Triangl (19 Proben) und Milada Horáková-Str./Pulverbrücke (31 Proben). Vom Gräberfeld im Lumbe-Garten wurden bislang lediglich zehn Proben erfolgreich analysiert. Von der geplanten Kontrollgruppe von Tieren wurden bislang zehn Proben vom II. Burghof analysiert.

Die ermittelten Werte $\left(\delta^{15} \mathrm{~N}=6,1 \pm 1,6 ; \delta^{13} \mathrm{C}=-21,0 \pm 0,5\right)$ entsprechen einem auf C3-Pflanzen aufgebauten Land-Ökosystem. Diese Werte stimmen gleichzeitig mit den im großmährischen Mikulčice ermittelten Daten überein. Bei bislang 69 analysierten menschlichen Proben kann die Nahrung der Population allgemein als terrestrisch mit variablem Anteil tierischer Proteine charakterisiert werden (Abb. 11). Die Werte der stabilen Kohlenstoffisotope $\left(\delta^{13} \mathrm{C}=-18,9\right.$ $\pm 0,6)$ liegen an der Grenze des nachweisbaren Verzehrs von C4-Pflanzen (Hirse). In unserer Gruppe kommen Individuen mit Werten vor, die zweifelsohne oberhalb dieser Grenze liegen, andererseits begegnet man aber auch solchen, deren Nahrung rein aus C3-Pflanzen zu bestehen scheint. Im Vergleich zur Population von Großmähren stellt dies auf den ersten Blick eine Abweichung dar. Die Nahrung der Bewohner der Prager Burg ähnelte vielmehr der bei der Untersuchung einer Gruppe aus dem polnischen Weiler Giecz ermittelten Nahrung, die in die Zeit des 11.-12. Jahrhunderts datiert wird. Es gibt den Anschein, dass Fisch bei der betreffenden Population - bis auf potenziell eine Ausnahme (siehe weiter unten) - kein wichtiger Bestandteil der Ernährung gewesen war. Das Fehlen von Fisch im Speiseplan ist ein Merkmal, das die Population der Prager Burg mit der Population des großmährischen Mikulčice verbindet.

Betrachtet man die ermittelten Werte im Rahmen der einzelnen Gräberfelder, lassen sich Unterschiede beobachten, die auf eine fortgeschrittene soziale Differenzierung im Rahmen der Population der Prager Burg und ihrer Umgebung hinweisen. Die an der Fundstelle Stř̌ešovice-Triangl über die Ernährung ermittelten Daten entsprechen sowohl durch ihre geringe Variabilität der Daten, als auch durch ihren geringen Anteil tierischer Proteine in der Nahrung, dem ländlichen Charakter der Gruppe. Die bislang größte Überraschung scheinen die Ergebnisse vom Gräberfeld Pulverbrücke/Milada Horáková-Str. zu sein. Obwohl dort ein ähnlicher sozioökonomischer Status wie in Střešovice vermutet wurde, tun sich die Isotopenwerte zwischen beiden Gruppen auf den ersten Blick voneinander unterscheiden. Im Unterschied zu Střešovice beobachten wir dort zwischen den Werten der Männer und Frauen einen beträchtlichen Unterschied. Dabei weisen die Männer sowohl für Kohlenstoff, als auch für Stickstoff im Durchschnitt überraschenderweise niedrigere Werte auf. Während die meisten Frauen eine der Gruppe aus Střešovice ähnliche Nahrung aufweisen, weichen die Werte der Männer viel deutlicher davon ab. Die Isotopendaten deuten auf die besondere Stellung der an der Fundstelle Milada Horáková-Str. bestatteten Bevölkerungsgruppe hin.

Die in der Gruppe auf dem II. Burghof und am Kriegergrab ermittelten Werte bestätigen die Vermutung einer hochwertigen Nahrung mit hohem Anteil an tierischen Proteinen. Bei der Analyse der Daten vom II. Burghof muss jedoch in Betracht gezogen werden, dass die Gesamtcharakteristik der Nahrung auf dem II. und III. Burghof vom unterschiedlich hohen Vorkommen an Männern und Frauen beeinflusst sein könnte. Die ersten Ergebnisse vom Gräberfeld im Lumbe-Garten siedeln diese Bevölkerungsgruppe hinsichtlich der Ernährung an der Grenze zwischen der ländlichen Gemeinschaft von der Fundstelle Střešovice-Triangl und der Elitegruppe vom II. Burghof an. 
Den bisherigen Ergebnissen nach entsprach die Nahrung auf den einzelnen Gräberfeldern in den meisten der beobachteten Fälle dem vermuteten, anhand den archäologischen Indikatoren definiertem sozioökonomischen Status. Eine Ausnahme von diesem Trend stellt das Gräberfeld in der Milada Horáková-Str. dar, wo die Daten auf die Existenz einer speziellen, wahrscheinlich stark differenzierten Bevölkerungsgruppe hinweist (Tab. 1).

\begin{tabular}{|c|c|c|c|c|c|}
\hline Gräberfeld & $\begin{array}{l}\text { Archäologische } \\
\text { Interpretation }\end{array}$ & $\begin{array}{l}\text { Anzahl der } \\
\text { Proben }\end{array}$ & $\begin{array}{l}\text { Ernährung gemäß Isotopen- } \\
\text { analyse der Nahrung }\end{array}$ & Vergleich & Bemerkungen \\
\hline Lumbe-Garten & $\begin{array}{l}\text { Mitglieder des } \\
\text { Fürstengefolges } \\
\text { und deren } \\
\text { Familienangehörige }\end{array}$ & 10 & $\begin{array}{l}\text { Hochwertige Ernährung } \\
\text { mit hohem Anteil tierischer } \\
\text { Proteine }\end{array}$ & $+/-$ & $\begin{array}{l}\text { Vorerst kleine } \\
\text { Probe mit großer } \\
\text { Datenstreuung }\end{array}$ \\
\hline $\begin{array}{l}\text { III. Burghof/ } \\
\text { Krieger-Grab } \\
\text { IIIN199 }\end{array}$ & $\begin{array}{l}\text { Angehöriger der } \\
\text { Elite }\end{array}$ & 1 & $\begin{array}{l}\text { Hochwertige Ernährung } \\
\text { mit hohem Anteil tierischer } \\
\text { Proteine }\end{array}$ & + & \\
\hline $\begin{array}{l}\text { II. Burghof - an der } \\
\text { Marienkirche }\end{array}$ & $\begin{array}{l}\text { Kirchenfriedhof }= \\
\text { Christen, höherer } \\
\text { sozialer Status }\end{array}$ & 8 & $\begin{array}{l}\text { Hochwertige Ernährung } \\
\text { mit hohem Anteil tierischer } \\
\text { Proteine, Verzehr von Fisch }\end{array}$ & + & \\
\hline Střešovice-Triangl & $\begin{array}{l}\text { Eher ländliches } \\
\text { Hinterland }\end{array}$ & 19 & $\begin{array}{l}\text { Geringeres Vorkommen } \\
\text { tierischer Proteine in der } \\
\text { Nahrung, homogene Gruppe mit } \\
\text { geringer Variabilität der Daten }\end{array}$ & + & \\
\hline $\begin{array}{l}\text { Pulverbrücke / } \\
\text { Milada } \\
\text { Horáková-Str. }\end{array}$ & $\begin{array}{l}\text { Eher ländliches } \\
\text { Hinterland }\end{array}$ & 31 & $\begin{array}{l}\text { Geringeres Vorkommen } \\
\text { tierischer Proteine in der } \\
\text { Nahrung, homogene Gruppe mit } \\
\text { geringer Variabilität der Daten }\end{array}$ & $+/-$ & $\begin{array}{l}\text { Die Gruppe enthält } \\
\text { eine separate } \\
\text { Bevölkerungsgruppe } \\
\text { mit spezifischer } \\
\text { Nahrung }\end{array}$ \\
\hline
\end{tabular}

Tab. 1. Vergleich der archäologischen Interpretation der beurteilten Gräberfelder und Ergebnisse der Isotopenanalyse der Nahrung.

Der vorliegende Beitrag entstand mit finanzieller Unterstützung des von der Förderagentur der Tschechischen Republik geförderten Projekts 14-36938G „Mittelalterliche Population im Zentrum und auf dem Lande. Archäologie, Bioarchäologie und Genetik auf den Gräberfeldern der Prager Burg, Mittel- und Ostböhmens" sowie mit der vom Ministerium für Kultur im Rahmen der institutionellen Finanzierung einer langfristigen konzeptuellen Entwicklung der Forschungsorganisation Nationalmuseum (DKRVO 2015/19 und 2016/19, 00023272) gewährten finanziellen Unterstützung.

PhDr. Jan Frolík, CSc., Archeologický ústav AV ČR, Praha, v. v. i., Letenská 4, 11801 Praha 1, Česká republika,frolik@arup.cas.cz

Mgr. Sylva Kaupová, Národní muzeum, Antropologické oddělení, Cirkusová 1740, 19300

Praha 9 - Horní Počernice, Česká republika,sylva_kaupova@nm.cz 